\title{
Implementation of the Sino-Vietnamese Fishery Agreement: Mainly Chinese Perspective
}

\author{
Yao Huang ${ }^{1}$, Mingming Huang ${ }^{2 *}$ \\ ${ }^{1}$ Faculty of School of Law, Sun Yat-sen University, Guangzhou, China \\ ${ }^{2}$ School of Law, Sun Yat-sen University, Guangzhou, China \\ Email: lpshyao@mail.sysu.edu.cn; *hmm-13@163.com
}

Received June 20 $0^{\text {th }}$, 2013; revised July 23 ${ }^{\text {rd }}$, 2013; accepted August 21 $1^{\text {st }}, 2013$

\begin{abstract}
Copyright @ 2013 Yao Huang, Mingming Huang. This is an open access article distributed under the Creative Commons Attribution License, which permits unrestricted use, distribution, and reproduction in any medium, provided the original work is properly cited.
\end{abstract}

\begin{abstract}
The Beibu Gulf (Gulf of Tonkin) is one of the main fishing grounds for both China and Vietnam. The Sino-Vietnamese Agreement on Fishery Cooperation in the Beibu Gulf is an important legal instrument to effectively manage and conserve fishery resources in the Gulf. This article reviews the implementation of the Agreement, analyzes the main factors attribute to the smooth implementation, discusses the main problems arising from the implementation and further presents some proposals for improvement.
\end{abstract}

Keywords: Sino-Vietnamese Fishery Agreement; Implementation; Maritime Delimitation; Law Enforcement; Institutional Mechanism

\section{Introduction}

Nationals and vessels of China and Vietnam have operated fishing activities in the Beibu Gulf (also called the Gulf of Tonkin, or the Beibu Bay) for a long history. Fisheries of the Gulf are of great importance to both countries. However, as the system of exclusive economic zone (EEZ) was established by the United Nations Convention on the Law of the Sea of 1982 (UNCLOS), traditional fishing activities in the Beibu Gulf suffered a lot. A considerable number of fishermen from both countries had to withdraw from their traditional fishing grounds in the Beibu Gulf, and fishery disputes between the two countries erupted frequently. Professor ZOU Keyuan pointed out that, "In the 1980s, due to the deterioration of relations between the two countries, there were a large number of incidents involving the detention and arrest of Chinese fishing vessels."1 Even though the relationship between China and Vietnam became normal and went towards smoothly, severe fishery conflicts, which caused great damage to the two countries, did not reduce but still happened a lot in the 1990s. ${ }^{2}$

Under such circumstances, on the basis of the Sino-Vietnamese Agreement on the Delimitation of the Territorial Sea, Exclusive Economic Zone and Continental Shelf between the Two Countries in the Beibu Gulf (hereinafter referred to as the Delimitation Agreement) signed on December 25, 2000, the Agreement on Fishery Cooperation in the Beibu Gulf between the Government of the People's Republic of China and the Government of the Socialist Republic of Vietnam (hereinafter

\footnotetext{
*Corresponding author.

${ }^{1}$ ZOU Keyuan, "Sino-Vietnamese Fishery Agreement for the Gulf of Tonkin,” The International Journal of Marine and Coastal Law 17(2002): 131.

${ }^{2}$ XUE Guifang, International Fisheries Law and Policy and China’s Practice (Qingdao: China Ocean University Press, 2007), (in Chinese) 221-224.
}

referred to as the Fishery Agreement or the Agreement) ${ }^{3}$ was signed in Beijing on the same day. From 2001 to April 2004, China and Vietnam negotiated the Supplementary Protocol to the Fishery Agreement (the Supplementary Protocol). Finally in April 2004, China and Vietnam signed the Supplementary Protocol and then the two States respectively ratified the Fishery Agreement which officially came into force on June 30, 2004.

Under the Fishery Agreement, the contracting parties establish a Joint Fishery Committee (JFC) to take charge of implementing the Agreement. The JFC promulgated the Regulations on Conservation and Management of the Fishery Resources in the Beibu Gulf (the Regulations). China and Vietnam signed the Regulations in April 2004.

The Fishery Agreement, the Supplementary Protocol and the Regulations mentioned above are the important normative documents for China and Vietnam to cooperate in managing, conserving and utilizing the fishery resources in the Beibu Gulf, among which the Fishery Agreement is the most important legal instrument. The Agreement establishes three types of the agreed water zones including the Common Fishery Zone (CFZ), Transitional Arrangement Zone (TAZ), Buffer Zone for Smallscale Fishing Boats, and it also prescribes different fishery management systems for the agreed water zones. Besides, the Agreement determines the quantity of the ships, areas and requirements of fishing in various water areas and so on. It establishes the cooperation framework and operational mechanism for China and Vietnam in the terms of fishery resources in the Gulf. The Supplementary Protocol prescribes the transitional arrangements and constitutes an integral part of the Fishery

\footnotetext{
${ }^{3}$ The Agreement is valid for 12 years and will automatically be extended another 3 years after its expiration. The Chinese version of this agreement is available at the website of Ministry of Foreign Affairs of the People's Republic of China, last checked September 5, 2012, http://www.fmprc. gov.cn/ chn/gxh/zlb/tyfg/t556668.htm.
} 
Agreement. The Protocol is applied to a part of the respective EEZ of the two countries north of the Common Fishery Zone. According to Article 11(1) of the Agreement, the transitional arrangement would be expired 4 years later since The Agreement took effect. The Regulations made specific provisions for the two countries on the conservation, management and sustainable utilization of the fishery resources in the Common Fishery Zone of the Beibu Gulf. Under Article 2 of the Regulations, the supervision organs of China and Vietnam are responsible for the supervision and investigation on the fishery activities and punishment on the illegal fishery behaviors in the Common Fishery Zone. The coordinated and liaison unit of China is the Fishery Administration and Fishing Port Superintendency Agencies while that of Vietnam is the Maritime Police Force.

It's worth noting that the Delimitation Agreement has provided a solid foundation for fishery cooperation between China and Vietnam in the Beibu Gulf since it has successfully delimited the maritime boundary of the two States in the Gulf including the boundary lines of the territorial sea, EEZ and continental shelf.

It has been over 8 years since the Fishery Agreement comes into effect. The purpose of this article is to review the implementation of the Agreement, analyze the main factors attribute to the smooth implementation, discuss the main problems arising from the implementation, and then put forward suggestions for improvement.

\section{Practice of Implementing the Fishery Agreement}

In the past over 8 years after the entry into force of the Fishery Agreement, what has been done by the contracting parties? What measures have been taken to implement the Agreement? We examine the questions from bilateral and unilateral level of the practice of China and Vietnam on putting into action what the Agreement provides.

\section{Bilateral Level}

For China and Vietnam, the signature and ratification of the Fishery Agreement created a win-win prospect for them. Therefore they exert great efforts to cooperate in the field of fishery management.

\section{Performing Work of the Joint Fishery Committee}

To rationally utilize and effectively manage fishery resources, according to the Fishery Agreement, China and Vietnam establish a Joint Fishery Committee (JFC) to implement the agreement. The functions of the JFC mainly include the followings: manage the agreed water zones, consult on matters related to cooperation, preservation, utilization of fishery resources, adopt regulations and implementing measures of fishery management, settle fishery disputes and so on. ${ }^{4}$

The Fishery Agreement prescribes that the JFC shall hold one or two meetings annually. ${ }^{5}$ And in practice, The JFC holds an annual meeting and two preparatory meetings each year, to determine the quantities of fishing vessels permitted to operate fishing activities in the agreed water zones, the plans of joint inspection and joint surveys on fisheries resources in the CFZ, and to deal with other relevant issues. Till to August 2012, the

\footnotetext{
${ }^{4}$ Article 13.3 of the Fishery Agreement.

${ }^{5}$ Article 13.4 of the Fishery Agreement.
}

JFC has held 9 annual meetings.

With the work of the JFC, from 2004 to 2009, the total number of Chinese fishing vessels, which were allowed to fish in the Vietnamese side in the agreed water zones, was around 5800 ships, and the power amount was about 1 million 4 hundred thousand horsepower. The number of Vietnam were around 9000 ships and 1 million horsepower ${ }^{6}$ Since ending the transitional arrangement in 2008, the JFC became the only institution which has the decisive power to make arrangement for fishery production in the Beibu Gulf. The number of fishing vessels of each party for fishing activities in the CFZ each year is 1543 boats, and the yearly power amount is 211,391 horsepower. $^{7}$ The JFC made decisions on the basis of the allowable catch, which was based on the results from joint regular surveys on fishery resources and the impact on respective fishing activities of both parties, and the need of sustainable development.

On the 9th annual meeting of the JFC, held on August 11, 2012, in addition to the routine session work, China and Vietnam reached agreements on the issues of conservation and management of fisheries resources. ${ }^{8}$ In recent years, the continuing increasing number of fishing vessels of Vietnam in the CFZ aggravates much more burden on fishery resources. There is a serious trend of over-exploitation of living resources in the agreed water zones. So China proposed to regulate the exploitation of fishery resources more strictly and conduct a fishing ban jointly. The representatives of Vietnam gave a positive response and considered to report to their government. This is a progress for Vietnamese side during the implementation of the Fishery Agreement. And then two sides both agreed to authorize the expert groups of fishery resources to discuss and put forward a specific scheme of the fishing ban, such as the closed season, the forbidden types of and plans of reduction of fishing vessels, and submit the scheme to the JFC on the next annual meeting in 2013. However, whether the Vietnamese response would get a good result and truly implement depends on the willingness and actions of its government.

The JFC has done a lot of work since it was established and made great contribution to manage fishery resources of the Beibu Gulf, especially the work of fair allocation of fishing quotas between the contracting parties.

\section{The Joint Marine Inspection}

After the Fishery Agreement took effect, relative departments of China and Vietnam, such as the navy, the fishery administration, the coastal guard, etc, have strengthened their cooperation. On the basis of strengthening supervision and administration in their respective own water zones, the two countries' law enforcement agencies continuously cooperate in

\footnotetext{
6“"The Implementation of the Sino-Vietnamese Fishery Agreement," China Fisheries News (in Chinese), June 7, 2010, p. 2.

${ }^{7}$ More detailed information see: The Fisheries Bureau of Ministry of Agriculture, China Fisheries Yearbook (Beijing: China Agriculture Press, 2010) (in Chinese), 23; China Fisheries Yearbook (Beijing: China Agriculture Press, 2011) (in Chinese), 22; "Fisheries of the Beibu Gulf are in stable order," The Fisheries Research Institute of the Yellow Sea (in Chinese), last modified September 14, 2011, http://www.ysfri.ac.cn/Newshow.aspshowid=1881\&signid = 25.htm,; "China and Vietnam strengthen fishery cooperation in the Beibu Gulf," Ocean and Fisheries Bureau of Jiangsu Province (in Chinese), last modified September 3, 2012, http://www.jsof.gov cn/art/ 2012/9/3/art_131_107323.html.

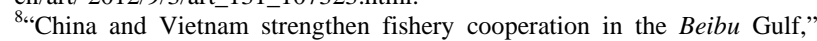
Ocean and Fisheries Bureau of Jiangsu Province (in Chinese), last modified September 3, 2012, http://www.jsof.gov.cn/art/2012/9/3/art_131_107323. html.
} 
exchanging of and sharing information in the agreed water zones.

According to the Fishery Agreement, the competent authorities of both parties, if necessary, may coordinate to conduct joint monitoring and inspection and to handle any breach of the Regulations. ${ }^{9}$ In view of the need to strengthen cooperation on implementation of the Fishery Agreement, China and Vietnam established a joint marine inspection mechanism of the Beibu Gulf to conduct joint patrols in the agreed water zones periodically. Since 2006, the two sides took a joint inspection each year and sent their fleets to take part in the joint patrol. ${ }^{10}$ There is also a meeting after finishing the joint inspection to review achievements of their action and make next plan. The joint inspection was conducted by the Chinese Fisheries Administration Department (its Chinese Pinyin: yuzheng bumen) and the Vietnamese Maritime Police Command.

Up to April 2012, China and Vietnam have jointly launched 7 joint inspections in the CFZ. ${ }^{11}$ The main tasks of the joint inspection include keeping records of fishing activities in the Gulf, taking necessary measures, such as monitoring, boarding and inspection, handling any breach of the Regulations, investigating and dealing with issues involving illegal fishing, rescuing the distressed fishermen of the two countries, and carrying out legal education to fishermen. ${ }^{12}$ The joint inspection team has educated and encouraged fishermen of both States to respect the regulations regarding the CFZ.

The mechanism of joint marine inspection is crucial to preserve and utilize fishery resources, to keep the safety and order of the Beibu Gulf. It shows the sincerity of both parties to comply with and implement the Fishery Agreement, to cooperate and maintain friendly relations.

\section{The Joint Surveys of Fishery Resources}

Under Articles 5, 6 and 17.1 of the Fishery Agreement, China and Vietnam shall jointly take measures in relation to preservation, management and sustainable utilization of the living resources, do joint regular surveys on fishery resources, and cooperate for fishery scientific research and preservation of marine living resources in the agreed water zones. To this end, China and Vietnam establish their expert groups respectively, as the wisdom tank of the JFC, to facilitate such cooperation, to take charge of monitoring fishery resources, and to put forward suggestions for fishery management. ${ }^{13}$ In order to better grasp the actual status of fishery resources, to provide more reliable scientific data for the JFC, the two sides also decided to conduct joint surveys on fishery resources every year since October,

\footnotetext{
${ }^{9}$ Article 9.3 of the Fishery Agreement provides that "The competent authorities of both parties, if necessary, may coordinate to conduct joint monitoring and inspection and to handle any breach of the regulations laid down by the Sino-Vietnamese Joint Fishery Committee in the Beibu Gulf concerning preservation and management of fishery resources."

10 "For the peace and harmony of the Beibu Gulf," South China Sea Region Fisheries Administration Bureau (in Chinese), last modified September 28, 2006,http://www.moa.gov.cn/sydw/nhyzj/gzdt/200609/t20060928_2110806. htm.

${ }^{11}$ “'The Fisheries Bureau of China and the Marine Police of Vietnam carry out joint marine inspection together in the Beibu Gulf,” Fisheries Information of the South China Sea (in Chinese), last modified April 26, 2012, http://www.nhyzchina. gov.cn/sites/MainSite/Detail.aspx? StructID = 3273 .

${ }_{12}$ "The implementation of the Sino-Vietnamese Fishery Agreement," China Fisheries News (in Chinese), June 7, 2010, p. 2.

${ }^{13}$ “The eleventh meeting of Sino-Vietnamese expert groups of fishery resources of the Beibu Gulf held in Guangzhou," South China Sea Region Fisheries Administration Bureau (in Chinese), last modified December 9, 2009, http://www.moa.gov.cn/ sydw/nhyzj/gzdt/200912/t20091207_2110444.htm.
}

2005. ${ }^{14}$ According to the Fishery Agreement and the specific survey plans, each party sent their survey ships to the CFZ to investigate the situation and changes of fishery resources by using a sample of observations. They also sent their researchers as observers to work with the other party to ensure all the data and information collected are reliable and accurate.

Till to June 2010, the two states have completed the joint investigation task of 2 phases and 17 voyages of fishery resources. ${ }^{15}$ The contents of the joint survey include: bottom trawl sampling, fishery environmental monitoring, and observation of fishing vessel distribution. At the end of each joint survey, the expert groups of fishery resources will hold regular scheduled meeting to prepare research plans, review progress they made, analyze the data collected in the survey, and do assessment on the situation and changes of fishery resources. And then the experts will deliver an annual survey report, which provides the reliable foundation of making conservation and management plans and technical support to the JFC.

The joint survey of fishery resources is an important measure to implement the Fishery Agreement. Because when the JFC determines the quantity of operating fishing vessels, it should make decision based on the results from joint regular surveys on fishery resources. Meanwhile, the joint survey provides reliable information to evaluate the situation and the change of fishery resources of the Beibu Gulf, and to make appropriate adjustment of fishery industry and other relevant measures of fishery management.

\section{Unilateral Level}

In addition to cooperate with each other, China and Vietnam have taken various measures domestically to implement the Fishery Agreement according to their own circumstances. In some degree, it means that each party had to take some painful steps necessary to shrink fishing grounds, cut back fishing fleets, and to reduce redundant labor in the field of fishery in order to implement the Agreement.

\section{Chinese Measures}

1) Legislative Measures

a) Before the Agreement's Coming into Force

Before the signature of the Fishery Agreement, the Fisheries Law of China was amended for the first time according to the "Decision of the Standing Committee of the National People's Congress on the Amendment of the Fishery Law of the People's Republic of China” at the Eighteenth Session of the Standing Committee of the Ninth National People's Congress on October 31, 2000. ${ }^{16}$ The important amendments mainly re-

\footnotetext{
14،"The sixth Sino-Vietnamese joint survey of fishery resources of the Beibu Gulf was completed," South China Sea Region Fisheries Administration Bureau (in Chinese), last modified May 11, 2007, http:// www.moa.gov. cn/sydw/nhyzj/gzdt/200705/t20070511_2110751.htm.

15،The implementation of the Sino-Vietnamese Fishery Agreement," China Fisheries News (in Chinese), June 7, 2010, p. 2.

${ }^{16}$ The Fisheries Law was amended for the second time on August 28th, 2004 after the Fishery Agreement came into force. But the version of 2004 is almost the same as the one of 2000, except article 16.1, which prescribes that,"The state shall encourage and support the breeding, cultivation and popularization of good aquatics. No new aquatic may be popularized unless it has been examined and approved by the National Committee for Examination and Approval of Original Breeding and Good Breeding and has been announced by the fishery administrative department of the State Council." The English version of the Fisheries Law of China (2004) is available at the website of the Investment in China, last checked November 5, 2012, http://www.fdi.gov.cn/pub/FDI_EN/Laws/GeneralLawsandRegulations/Basi cLaws/t20060620_50950.jsp.
} 
ferred to provisions of three parts: Fishing, Increase and Protection of Fishing Resources, and Legal Liability. These amendments reflected the necessary adjustments to the new circumstances of China.

In 2004, to ensure the effective implementation of the Fishery Agreement, China's relevant authorities, including the central or local levels, issued a series of legislative documents on the implementation of the Fishery Agreement.

The Ministry of Agriculture of the People's Republic of China issued several circulars on implementation of the SinoVietnamese Fishery Agreement. The first one was "the Emergent Circular on the Preparation of Implementing the SinoVietnamese Fishery Agreement"17, which was released on June $14^{\text {th }}, 2004$. This circular emphasized the preparatory work of the implementation, including allocating fishing quotas to specific fishing boats, conducting a comprehensive inspection on those fishing vessels with permission. The inspection focused on whether the vessel hoisted national flag and was marked clearly, as well as other relevant certificates. It also required fishery departments to carry out educational and training programs, which enable fishermen to consciously abide by the Fishery Agreement and other important regulations.

The second was the "Circular on Implementation of the Sino-Vietnamese Fishery Agreement"18, released on June $15^{\text {th }}$, 2004. It prescribed that fishing vessels entering into the agreed water zones must obey the Fishery Agreement, the Supplementary Protocol, and the Fishery Regulations. Those vessels permitted into the Vietnamese waters, especially needed to comply with the Vietnamese laws. This circular reiterated the overall requirements for fishing vessels and encouraged citizens to report illegal fishing activities to competent departments.

The coastal provinces issued similar circulars too. For instances, Hainan Province issued an "Emergent Circular on Making a Good Preparation for the Implementation of the SinoVietnamese Fishery Agreement" ${ }^{\text {19 }}$, released on $23^{\text {rd }}$ June, 2004, which underscored the management of fishing activities and established a special leading group to implement the Fishery Agreement. Also, Beihai city of Guangxi Province made public the information related to the number of fishing quotas. The notice of Beibai city, issued on June 30, 2004, promulgated a specific working scheme, including the application, approval and publicity of allocating fishing quotas to fishermen. ${ }^{20}$

b) After the Agreement's Coming into Force

The General Office of the State Council of China also issued a circular on strengthening the administration of foreign-related fishing activities on August $9^{\text {th }}, 2004$. In this circular, the General Office required the administrative departments for fishery

\footnotetext{
17 "Emergent Circular on the preparation of Implementing the Sino- Vietnamese Fishery Agreement," Ministry of Agriculture of the People's Republic of China (in Chinese), last modified June 14, 2004, http://www.moa. gov.cn/zwllm/zxfb/201007/t20100702_1592501.htm.

18 "The Ministry of Agriculture of China issues the circular on implementing the Sino-Vietnamese Fishery Agreement," China Enterprise Integration (in Chinese), last modified June 15, 2004, http://www. jincao.com/fa/25/law 25.93.htm.

19 “General Office of the People’s Government of Hainan Province Released an Emergent Notice on Making a Good Preparation for the Implementation of the Sino-Vietnamese Fishery Agreement which will take effect soon”, the Find-Law (in Chinese), last modified June 23, 2004, http://china.findlaw.cn/ fagui/jj/25/110604.html.

20 "The Office of People's Government of Beihai transmits a Notice on the Implementation Program of the Sino-Vietnamese Fishery Agreement issued by the Beihai Aquatic Products Bureau," the Law Library (in Chinese), last modified June 30, 2004, http://www.law-lib.com/ law/law_view.asp?id = 146449.
}

at various levels shall strictly implement the Fisheries Law, the bilateral fishery agreements and relevant regulatory provisions made between China and relevant foreign countries, and strengthen the law enforcement. ${ }^{21}$

Because the Fishery Agreement involves the matters of the management of marine boundary, fishing activities, maritime supervision arrangements and so on, whether the Fishery Agreement can be implemented in good faith has great impacts on the interests of the countries and fishermen. These above implementary legislative documents played an important role in effectively implementing the Agreement and making appropriate arrangements for the domestic issues.

2) Executive measures

a) Carry out Propaganda of the Agreement and Occupational Training

Although the Delimitation Agreement and the Fishery Agreement had come into effect, many fishermen still could not abide by the regulations consciously due to economic impetus and lack of education. Fishery disputes between the two countries still occur from time to time. If disputes could not be handled properly, they not only cause damages to the fishermen, but also do harm to the relationships between the two countries.

In this regard, fishery departments of China have actively carried out various forms of publicity of relevant legal instruments and educational activities. In 2005, the Ministry of Agriculture of China decided to spend 3 years on educational and training programs, which mainly aimed at educating the owners, captains and chief officers of large fishing vessels and gradually establishing a whole legal system of training and education. In the next year, legal training programs for fishermen were carried out by the three coastal provinces, including Guangdong, Guangxi and Hainan. ${ }^{22}$ The specific contents of training programs are some basic knowledge, including the international law of the sea, the Delimitation Agreement and the Fishery Agreement, communication and emergency evacuation, safe production standards and settlements for fishery disputes. The relevant departments also delivered nearly one hundred thousand copies of important materials, such as "the fishing instructions in the Beibu Gulf" and "demarcation chart of the Beibu Gulf” to fishermen from 2004 to $2010 .{ }^{23}$ Through publicity and training, most crews of fishing vessels enhanced their legal awareness gradually, and the number of cases of illegal production and fishery disputes dropped significantly. The training programs not only focused on the rules of fisheries, but also involved other occupation trainings. Besides, the coastal provinces held many training programs for the law enforcement

\footnotetext{
21 "The Circular of the General Office of the State Council on Strengthening the Administration of Foreign-related Fishing Activities”, Law Information of China, last modified August 9, 2004, http://www.lawinf ochina.com/ display. aspx?lib $=$ law\&id $=3713 \&$ paycode $=$ 43B0D2C5DD0BCF700 B163F2B0BC078A239848666E049F4051FDF297F7B7AB43E\#.

${ }^{22}$ See: "Training Work for foreign-related fishing crew of Guangxi is fully underway,” Fisheries Administration Bureau of the South China Sea Region (in Chinese)," last modified July 27, 2006, http://www.moa.gov.cn/sydw/ nhyzj/gzdt/200607/t20060727_2110829.htm;“'Hainan Province attaches great importance to the training work for foreign-related fishing crew,” Fisheries Administration Bureau of the South China Sea Region (in Chinese), last modified August 7, 2006, http://www.moa.gov.cn/sydw/nhyzj/gzdt/200608/ t20060807_2110822.htm.

23 "The implementation of the Sino-Vietnamese Fishery Agreement," China Fisheries News (in Chinese), June 7, 2010, p. 2.
} 
officials to strengthen the law-enforcement too. ${ }^{24}$

At the end of 2009, on a voluntary basis, three provinces of Guangxi, Guangdong and Hainan accumulatively spent almost RMB 458 million Yuan to reduce 5,129 fishing boats, to train around 28,470 fishermen, and partially solved the fishermen's livelihoods problems. ${ }^{25}$

b) Conduct Summer Fishing Ban

Since overfishing led to serious depletion of fisheries resources, China enacted an annual fishing ban (also called midsummer moratorium system or closed fishing seasons) ${ }^{26}$ for two months in summer in the north-western part of the South China Sea (including the Beibu Gulf) from 1999 (later, the period of fishing ban was prolonged to two months and a half). The fishing ban is a kind of customary management method, whose general purposes are to reduce harvesting pressure, to protect spawning aggregations and prevent the disturbance of more highly favored fish species. ${ }^{27}$ According to the Chinese fishing ban, any fishing vessel that enters into the regulated areas during the banned period would be subjected to punishment and its catches would be confiscated.

Some positive outcomes result from performing the fishing ban. Firstly, the fishery resources are given certain time to restore or rebuild. Secondly, opportunities for adjusting industrial structure are provided for the coastal provinces. Take Guangxi Autonomous Zone for an example, by carrying out the fishing ban, Guangxi accelerates the adjustment of its fishery industry structure, and timely eliminates those fishing vessels which do not meet requirements laid down by the relevant departments. ${ }^{28}$ As an expert said that the fishing ban is one of the most important measures that China took to restore and maintain its marine living resources and shows China's image as a responsible fishing country. ${ }^{29}$

c) Strengthen Law Enforcement to Control Overfishing and Combat with Illegal Fishing

Before the Fishery Agreement came into force, China had made great efforts to control overfishing, and prescribed the fisheries quota policy and fishing license in its Fisheries Law. In practice, in order to better fulfill its obligation under the Fishery Agreement, China enforces the system of fishing license much more strictly. In recent years, The Ministry of Agriculture of China urged the relevant coastal provinces to for-

\footnotetext{
24 "Concentration on the Annual Propaganda and Popularization of the Fishery Law in the Region of the South China Sea,” South China Sea Region Fisheries Administration Bureau (in Chinese), last modified December 6, 2007,http://www.moa.gov.cn/sydw/nhyzj/gzdt/200712/t20071206_2110673. htm. 25 "The Implementation of the Sino-Vietnamese Fishery Agreement," China Fisheries News (in Chinese), June 7, 2010, p. 2.

${ }^{26}$ The government of Vietnam also calls it as fishing holiday season. See "Vietnam protests Chinese unilateral fishing ban in the East Sea ", available at the Ministry of Foreign Affairs of Vietnam, last checked October 25, 2012, http://www.mofa.gov.vn/en/tt_baochi/pbnfn/ns12012 3233459/view; The detailed information of the fishing ban see: "The Ministry of Agriculture of China released the circular on the 2011 summer fishing ban in the South China Sea,” Fisheries Administration Bureau of South China Sea Region (in Chinese), last modified May 13, 2012, http://www.moa.gov.cn/sydw/nhyzj/xzwg /201105/t20110513_2111034.htm.

${ }^{27}$ Joshua E. Cinner and Shankar Aswani, "Integrating customary management into marine conservation,” Biological Conservation 140 (2007): 204. ${ }^{28}$ WU Zhi-de, ZOU Jian-wei and FU De, "Problems and countermeasures of implementing summer fishing closure season in Guangxi Province,” Chinese Fisheries Economics (in Chinese) 2 (2009): 16.

${ }^{29}$ CUI Lifeng, "Adapt to the new ocean legal system and promote the healthy development of marine fisheries -- In commemoration of the 30th anniversary of signing the United Nations Convention on the Law of the Sea,” China Fisheries News (in Chinese), September 24, 2012, 1.
}

mulate and implement fishing vessels scrapping programs to control fishing capacity ${ }^{30}$. China gives financial support to operate these programs. To ensure the effective implementation, some regulations on using this special fund were made ${ }^{31}$, and the relevant fishery departments will review the execution of these programs every year.

Some scholars noted that illegal fishing is a detriment difficult to eliminate. It not only generates harmful effects on economic and social welfares, but also further reduces incentives to comply with rules. ${ }^{32}$ So, in order to combat with illegal fishing, China launched the first joint patrol in its own sea areas of the agreed water zones on the day when the Fishery Agreement took effect. Then in September 2004, China formally established a stable mechanism of joint maritime supervision, which consists of the Chinese Fisheries Administration Department (Chinese Pinyin: yuzheng bumen) and the Coastal Guard (Pinyin: bianfang haijing), to take maritime joint inspection. ${ }^{33}$ This domestic joint supervision team has the similar responsibilities as the bilateral one, which was constituted by China and Vietnam. It also takes marine patrols, rescues endangered fishermen, monitors fishing activities and combats with other illegal activities, such as armed robbery at sea. It is worthy of mentioning the South China Sea Region Fisheries Administration Bureau (Pinyin: "nanhaiqu yuzhengju”), which is a department of the Fisheries Bureau of the Ministry of Agriculture. As one of the major law enforcement agency, the Bureau has two main objectives. First, it sends fishery administration ships to escort Chinese fishing vessels when they operate in the agreed water zones. Second, it prevents trespass and illegal fishing in the Chinese sea areas by boarding, inspecting and expelling fishing vessels, and so on. The Bureau plays an important role in implementing the Agreement.

Since 2010, the joint inspection team has increased the cruising ship from 1 boat to over 2 boats in the daily supervision, and established a rapid response mechanism to deal with emergent alarms. ${ }^{34}$ To effectively minimize foreign-related fishing conflicts during the law enforcement and avoid the loss caused by such events, Guangxi Province especially made an “Emergency Plan for Foreign-related Fishing” and established a headquarters for dealing with the emergency of foreign-related fishing activities. ${ }^{35}$ In addition, the coastal provinces have carried out special fishing escorting actions (Pinyin: zhuanxiang huyu xingdong) to strengthen the maritime and port inspection. For example, Hainan Province strengthened Fisheries Law enforcement to fight against pirates, robberies, destructive fish-

\footnotetext{
30 "The Ministry of Agriculture of China urges relevant coastal provinces to formulate fishing vessels scrapping programs to control fishing capacity," the NetEase, last modified January 4, 2005, http://news.163. com/50104/3/ 197K5IUG0001124T.html.

${ }^{31} 1_{\text {c }}$ The General Office of the Ministry of Finance and the General Office of the Ministry of Agriculture issue 'the regulations on management of using special fund for fisherman who change their jobs'," China Fisheries Administration (in Chinese), last modified November 5, 2003, http://www.moa.gov. cn/sjzz/yzjzw/fzghyzj/xmdtfzgh/200311/t20031105_2676486.htm.

${ }^{32}$ Huiguo YU and Yunjun YU, "Fishing capacity management in China: Theoretic and practical perspectives,” Marine Policy 32 (2008): 357. In this article, the authors discuss the issue of fishing capacity management in China from theoretic and practical perspectives, and analyze the measures China has taken in detailed.

${ }^{33}$ WU Zhuang, "Innovate the mode of joint fisheries inspection of the Beibu Gulf," China Fisheries News (in Chinese), July 10, 2006, p. 2.

${ }^{34}$ The Fisheries Bureau of Ministry of Agriculture, China Fisheries Yearbook (Beijing: China Agriculture Press, 2011) 134.

35“"Guangxi issues emergency plans for foreign-related fishing," China Fisheries News (in Chinese), November 15, 2010, 2.
} 
ing activities in particular. ${ }^{36}$ The fishery administrations of Guangxi Province have conducted many maritime law enforcement actions since May 1, 2011. They launched a number of comprehensive cruise inspection activities in Chinese own water areas of the CFZ. Their inspective jobs focus on whether fishing vessels are marked obviously and correctly, whether fishing vessels operate fishing activities with necessary and legal certificates, and using legal fishing methods. ${ }^{37}$

The Ministry of Agriculture of China promulgated "the Regulation on Administrative Law Enforcement of Fisheries Inspection” on the May 22, 2009. ${ }^{38}$ It aims to gradually establish a mechanism of all levels of supervision and inspection of fisheries law enforcement, and ensure the implementation of fishery laws and regulations. This Regulation contains 24 articles, which cover the subject, principle, content, procedure, and legal liability of the administrative law enforcement of fisheries inspection.

d) Prioritize Proliferation and Protection of Fishery Resources

China has paid much attention to the issues of marine scientific research, proliferation and protection of fishery resources. Article 5 of the Fisheries Law of China provides that, "People's governments at various levels shall give moral encouragement or material awards to entities and individuals who make outstanding contributions to the increase and protection of fishery resources, to development of fishery production, or to research in fishery science and technology." And Part 4 of this Law especially prescribes the issues of increase and protection of fishing resources in detailed.

In recent years, the coastal provinces, like Hainan and Guangxi, have organized many large-scale marine living resources proliferation actions respectively, which produced both economic and biologic benefits. ${ }^{39}$ Since 2005, the Bureau of Fisheries of Ministry of Agriculture has been applying for a special fund to trace and support assessment of the implementation and effect of fishery resources proliferation. ${ }^{40}$ This work has effectively promoted the development of proliferation. In 2010, China worked on establishment of protected areas, proliferation and construction of artificial reefs actively with investment of over RMB 85 million Yuan. ${ }^{41}$

\section{Vietnamese Measures}

1) Legislative Measures

In 2003, Vietnam promulgated its fisheries law. ${ }^{42}$ The Law

${ }^{36}$ LIANG Zhenqiu, Hainan Yearbook (Haikou: Hainan Yearbook Press, 2011) (in Chinese), 259.

37 "Guangxi obtains good results from escorting action and marine patrol in the EEZ in 2011," China Fisheries Administration (in Chinese), last modified December 9, 2011, http://www.moa.gov.cn/sjzz/ yzjzw/yyzfyzj/zhyyzf/ 201112/t20111209_2717509.htm.

38“"Regulation on Administrative Law Enforcement of Fisheries Inspection," Law Education of China, last modified May 22, 2009, http: //www.chinalawedu. com/new/1200_22016__/2009_6_2_li44171925 5012690024669.shtml.

${ }^{39}$ LIANG Zhenqiu, Hainan Yearbook (Haikou: Hainan Yearbook Press, 2011) (in Chinese), 259; "Proliferation of living resources of the Beibu Gulf was held in Beihai City," South China Sea Region Fisheries Administration Bureau (in Chinese), last modified June 16, 2008, http://www.moa.gov.cn /sydw/nhyzj/gzdt/200806/t20080616_2110613.htm; ZOU Jianwei, LIN Jiangjin and MU Yongtong, "Review and suggestion on decreasing of marine fishing vessels \& fishers' quitting fishing in Beihai, Guangxi,” Chinese Fisheries Economics (in Chinese) 6 (2007): 63.

${ }^{40}$ QIU Yongsong, ZENG Xiaoguang, CHEN Tao, WANG Yuezhong and YUAN Weiwen, The fishery resources and fishery management of the South China Sea (Beijing: Ocean Press, 2008) (in Chinese), 226.

${ }^{41}$ The Fisheries Bureau of Ministry of Agriculture, China Fisheries Yearbook (Beijing: China Agriculture Press, 2011) (in Chinese), 134.

42 "Law on Fisheries of Vietnam," in China-Asean Inspection and Quarantine Information Web, last modified November 29, 2010, http://caexpo. gxciq.gov.cn/html/2010-11/98.htm. on Fisheries of Vietnam was adopted on November 26, 2003 by the XIth National Assembly of the Socialist Republic of Viet Nam at its 4th session, and took its implementation effect as from July 1, 2004, almost the same time as the Sino-Vietnamese Fishery Agreement.

In the past, "a lack of capacity and the use of top-down decision making strategies have further led to uncertainty and mistrust of authorities inclined to use coercion and fines to implement government decisions”43. To change this adverse situation, Vietnam began its renovation of fishery management by supporting the idea of decentralized management of fisheries in the Law on Fisheries. This Law on Fisheries of Vietnam authorizes the local governments more competences and meanwhile more obligations in fishery management, in case of necessity, and if obtaining the approval of the Ministry of Fisheries, the People's Committee of the provinces or centrally-run cities shall announce additional contents or measures to make relevant rules suitable to the actual activities of exploiting resources in their localities. $^{44}$ The Final Report of Fisheries and Aquaculture Sector Study of Vietnam in 2005 (hereinafter referred to as Final Report 2005) pointed out that the new Law on Fisheries provides a good basic framework for fisheries management and the enforcement of the this Law is a step available to the Vietnamese government to take more effective actions. ${ }^{45}$

It is crucial that laws be harmonized so that a legislation or enforcement vacuum can be avoided, as pointed out by Professor Kuan-Hsiung Wang ${ }^{46}$. Accordingly, in recent years, Vietnam issued the rules for the implementation of the Law on Fisheries and several decrees related to fishing activities. For instance, the Decree on Regulations on Penalizing Administrative Violations in the Fisheries Field, which took effect on 15th May 2010, shall apply to organizations and individuals at home and abroad that commit administrative violations in the fisheries field in Vietnam and they will be penalized under the provisions of this Decree. ${ }^{47}$ Also, the Decree on Management of Fisheries Activities of Foreign Ships in Vietnam's Sea Areas took effect on June 1, 2010. This Decree applies to owners of foreign fishing vessels engaged in fisheries activities in Vietnam's sea areas and concerned agencies, organizations and individuals, and provides for the conditions, procedures and authority of granting licenses for fisheries activities; responsibilities of owners of foreign fishing vessels engaged in fisheries activities in Vietnam's sea areas, also responsibilities of state management agencies for fisheries activities of foreign fishing vessels in Vietnam's sea areas: examination, control and handling of administrative violations, and complaints and denunciations related to fisheries activities of foreign fishing vessels in Vietnam's sea areas. ${ }^{48}$

\footnotetext{
${ }^{43}$ Derek Armitage, MelissaMarschke, TruongvanTuyen, "Early-stage transformation of coastal marine governance in Vietnam?”, Marine Policy 35(2011): 705. ${ }^{44}$ Article 8.4 of the Law on Fisheries of Vietnam.

${ }^{45}$ Final Report of Fisheries and Aquaculture Sector Study of Vietnam (Ministry of Fisheries and The World Bank, February 16, 2005), (iii), last October 18, 2012, http://siteresources.worldbank.org/INTVIETNAM/Resources/ vn_fisheries-report-final.pdf.

${ }^{46}$ Kuan-Hsiung Wang, "Bridge over troubled waters: fisheries cooperation as a resolution to the South China Sea conflicts,” The Pacific Review Vol 14 No.4 (2001): 545.

${ }^{47}$ "Decree on regulations on penalizing administrative violations in the fisheries field", Authority of Foreign Information Service, accessed October 22, 2012, http://vietnam.vn/ decree-on-regulations-on-penaliing- administrative-violations-in-the-fisheries- field-c1071n20111010095835140.htm.

${ }^{48}$ "Decree on management of fisheries activities of foreign ships in Vietnam's sea areas", Authority of Foreign Information Service, last checked October 22, 2012,

http://moj.gov.vn/vbpq/en/_layouts/printeng.aspx?id=10619.
} 
Although these legislative measures apply in national wide, not only to the Beibu Gulf, they still push forward the implementation of the Fishery Agreement and have positive impacts on conserving and managing fishery resources.

2) Executive Measures

Vietnam has also made great efforts to implement the Agreement. Besides diversified cooperation with the government of China and the Chinese coastal provinces in the Beibu Gulf, such as Hainan Province ${ }^{49}$, Vietnam established a subcommittee of the Joint Fishery Committee, which plays a key role in implementing the Agreement. The sub-committee is required to make periodical reports on the number of Vietnamese and Chinese fishing vessels operating in the CFZ, and oversee security and national defense inspection in this region. It takes a vast of responsibilities for instructing the implementation of the Fishery Agreement domestically, holding regular meetings, focusing on issues concerning the preservation and sustainable development of marine resources in the CFZ, and bilateral cooperation in fisheries management. In addition, it processes reports sent by localities, coast guards, border guards, executive agencies and the Chinese side, and then make proposals to the government. The Vietnamese sub-committee is further required to update the list of Vietnamese fishing ships, which have registered to operate in the CFZ, and to grant fishing licenses to Vietnamese vessels which meet the conditions set up by fisheries regulations. ${ }^{50}$

In the fishery sector, "Vietnam is faced with a large number of small fishing vessels and fishermen which leads to overexploitation of marine resource". ${ }^{51}$ Confronting such a severe situation of recession of fishery resources in the Beibu Gulf, Vietnam realized that it should take some measures to conserve and manage the fishery resources. Thus, the Final Report (2005) emphasized the implementation of the Fishery Agreement and suggested the government move forward by taking the following steps: to establish strategic, closed fishing seasons; to introduce a compulsory logbook system and a license limitation program; to support scientific research and so on. ${ }^{52}$ In order to control overfishing, the Ministry of Fisheries of Vietnam limits the fishing effort in each fishing ground, and revises the fishing effort every 5 years. According to the Law on fisheries, the eligibility for annual fishing licenses of fishing vessels is based on crew size, engine capacity and gear type.

Due to the decrease of traditional fishing grounds after the demarcation of the Beibu Gulf, too many fishing boats have to operate fishing activities and compete with each other in a much smaller sea areas. In order to minimize and prevent the conflicts between the small-scale fishing vessels and the large

\footnotetext{
$\overline{49 \text { “Vietnam, Hainan speed up economic cooperation,” the Vietnam Plus, last }}$ modified September 7, 2009, http://en.vietnamplus.vn/Home/VietnamHainan-speed-up-economic-cooperation/20097/678.vnplus.

50 "Ministry of Foreign Affairs of Vietnam: Vietnam - China Sub- committee for Fisheries Cooperation operation strengthened," last mo- dified March 21 2005, http://www.mofa.gov.vn/en/nr040807104143/nr040807105001/ns05 0317085215/view.

${ }^{51}$ Nopparat Nasuchon, "Coastal management and community management in Malaysia, Vietnam, Cambodia and Thailand, with a case study of Thai fisheries management," Division for Ocean Affairs and the Law of the Sea Office of Legal Affairs, the United Nations, New York, 2009, 22. last checked November 1, 2012 http://www.un.org/depts/los/nippon/ unnff_programme_ home/fellows_pages/fellows_papers/nasuchon_0809_thailand.pdf.

${ }^{52}$ Final Report of Fisheries and Aquaculture Sector Study of Vietnam (Ministry of Fisheries and The World Bank, February 16, 2005), 43, last checked October 18, 2012, http://siteresources.worldbank.org/INTVIETNAM/Resources/vnfisheries-report-final.pdf.
}

ones, Vietnam also adopted a sub-regional fishing system, which allows certain type of fishing vessels enter into certain sea areas to fish. ${ }^{53}$ Vietnam also took other measures to implement the Fishery Agreement. For example, Vietnam has built a stronger maritime patrolling force and sent more ships to its own sea areas in the agreed water zones to keep monitoring and surveillance on fishing activities, and adopted the comanagement mechanism as an alternative fisheries management policy to avoid the ineffectiveness in policing or resolving fisheries conflicts. ${ }^{54}$

\section{Factors Attribute to Smooth Implementation of the Agreement}

By reviewing the practice of implementation, it is not difficult to see that the management of fishery resources in the Beibu Gulf has been effective. Generally speaking, there are some good results obtained in the past 8 years for China and Vietnam. The most important one is that fishery disputes reduced significantly and fishery activities performed orderly.

Before China and Vietnam signed the Delimitation Agreement of the Beibu Gulf, "the lack of an agreed-upon boundary in the Gulf caused disputes between fishermen from the two states and presented the opportunity for illegal activities in maritime areas close to the coasts." 55 Professor Tønnesson said that he experienced at first hand the deep resentment felt by Hainanese fishermen towards the Vietnamese government during a visit to Hainan in January 2000, because there have been many incidents in which Hainanese fishermen have been apprehended by the Vietnamese coastguard. ${ }^{56}$ Even though the Fishery Agreement was signed in 2000, before it came into force, some scholars still kept a cautious attitude by questioning how effectively the agreement would be implemented. And in practice, conflicts related to fishery between the two countries still happened a lot. Take the year of 2003 as an example, severe conflicts erupted many times. On September 23, 2003, Vietnamese armed ships attacked fishing boats of China in the Beibu Gulf, and there were another 5 Chinese fishing boats under seizure of Vietnam. ${ }^{57}$ And in late October of that year, Vietnam seized Chinese fishing vessels again. ${ }^{58}$ A statistical data of 2003 from Beihai Fishery Station of Guangxi Province showed that 18 fishing vessels of this city were detained by the authority of Vietnam, and caused direct economic loss over RMB 1 million Yuan. ${ }^{59}$

Through the great efforts made by both China and Vietnam, the situation of fishery disputes changed gradually. With the

${ }^{53}$ Ma. Carmen A. Ablan and Len R. Garces, "Exclusive Economic Zones and the Management of Fisheries in the South China Sea,” In A Sea Change: The Exclusive Economic Zone and Governance Institutions for Living Marine Resources, edited by Syma A. Ebbin, Alf Håkon Hoel, Are K. Sydnes, 142. last checked October 10, 2012, http://link.springer.com/chapter /10.1007/1-4020-3133-5_9\#page-1.

${ }^{54}$ Robert Pomeroy et al., "Fish wars: Conflict and collaboration in fisheries management in Southeast Asia,” Marine Policy 31(2007): 647.

${ }^{55}$ Nguyen Hong Thao, "Maritime Delimitation and Fishery Cooperation in the Tonkin Gulf,” Ocean Development \& International Law 36 (2005): 26.

${ }^{56}$ Stein Tønnesson, "Sino-Vietnamese Rapprochement and the South China Sea Irritant,” Security Dialogue, 34 (2003): 64.

${ }^{57}$ WANG Mengxia, "Waves are blowing in Northern Ports," China Ship Survey (in Chinese), October 2003: 32-34.

${ }^{58}$ WANG Mengxia, "Reflections over the 'BeiBuWan Event'," China Ship Survey (in Chinese), November 2003: 31.

59،The Fisheries Evolution of the Beibu Gulf: Employment of Vietnamese due to Labor Shortage,” the Global (in Chinese), last modified May 23, 2012 http://china.huanqiu.com/border/2012-05/2747257.html. 
active measures to prevent and stop illegal fishing activities by the Chinese government, fishermen of China learned to obey the Fishery Agreement and other relevant rules in the Beibu Gulf and foreign-related fishery disputes decreased year by year. ${ }^{60}$ In 2007, there is nothing of the occurrence of Chinese foreign-related fishery case in the Beibu Gulf $f^{61}$ and there were seldom reports on Sino-Vietnamese fishery conflicts in the recent years. It seems that the following factors make the implementation of the Agreement to achieve positive results.

\section{The Successful Delimitation of the Maritime Boundary in the Gulf}

Actually, unsettled maritime delimitation results in maritime disputes, including ones concerning the sovereignty over islands, EEZ and continental shelf. Considering of a fact that "the establishment of maritime boundaries may often impinge on traditional fishing activities”,62, to avoid the adverse impact of the demarcation in the Beibu Gulf had on the fisheries in greatest extent, China insisted to solve the issue of fisheries and the delineation of the maritime boundary at the same time. After long-term negotiations, China and Vietnam finally reached agreements on the issues of the maritime delimitation and fisheries cooperation in the Beibu Gulf. The successful delineation of this maritime boundary creates favorable conditions for fishery management by clarifying the allocation of the CFZ and the TAZ. Hence, it can avoid the sensible territorial disputes when implementing the Fishery Agreement. That is to say, as the Fishery Agreement was signed on the basis of delimitation of maritime boundary between China and Vietnam, the scope of the sea areas under the jurisdiction of each party is clear and specific. On one hand, the fishermen would be more cautious to operate fishing activities in their country's jurisdictional waters without crossing the definite boundary line. On the other hand, the law enforcement officers of each party would be able to enforce their domestic laws and regulations in certain sea areas and avoid unnecessary conflicts over law enforcement. So the delimitation of maritime boundary is conducive for compliance with the Fishery Agreement. Once the issue of maritime delimitation was settled, the contracting parties could focus on the issue of utilization, conservation and management of fishery resources. Without the sovereign dispute in the agreed water zones, as a number of scholars have stated, in the field of regional or sub-regional maritime cooperation, fisheries cooperation maybe easier to achieve since it is of lower sensitivity and less cost. ${ }^{63}$

Having a look at the state practices concerned, "it is natural that some joint fishing zones were adopted throughout the world, as provisional arrangements before the final delimitation." ${ }^{64}$ However, the Sino-Vietnamese Fishery Agreement is

\footnotetext{
${ }^{60}$ WU Zhuang, "Innovate the mode of joint fisheries inspection of the Beibu Gulf,” China Fisheries News (in Chinese), July 10, 2006, p. 2.

${ }^{61}$ LIU Yusong, "The five years of the implementation of the Fishery Agreement: Interview of $\mathrm{Wu}$ Zhuang, Director of the South China Sea Fisheries Administration Bureau of Ministry of Agriculture," China Fisheries (in Chinese) 7 (2009): 5.

${ }^{62}$ Huan-Sheng Tseng and Ching-Hsiewn Ou, "The Evolution and Trend of the Traditional Fishing Rights,” Ocean \& Coastal Management 53 (2010): 272.

${ }^{63}$ See Nguyen Dang Thang, "Fisheries Cooperation in the South China Sea and the (Ir) relevance of the Sovereignty Question,” Asian Journal of International Law 2 (2012): 85.

${ }^{64}$ Sun Pyo Kim, "The UN Convention on the Law of the Sea and new fisheries agreements in North East Asia,” Marine Policy 27(2003): 97.
}

different of that since it was closely linked to and based on the maritime delimitation. Thus, in some extent, it is a long-term arrangement for fisheries of the Beibu Gulf.

\section{Practical Arrangements for Fishery Management}

Fishery resources differ from other nonliving resources since the former are migratory and care nothing about the boundary divided by human being. Therefore, although the Delimitation Agreement provides a solid foundation for two parties to cooperate in the field of fisheries in the Beibu Gulf, in view of the specialty of fishery resources, China and Vietnam still need to make proper and practical arrangements for fisheries. At this point, the contracting parties did a good job.

\section{The Fishery Arrangements in the Agreed Water Zones}

The Fishery Agreement establishes a Common Fishery Zone and a Transitional Arrangement Zone in the Beibu Gulf, within which different fishery arrangements were given.

The Common Fishery Zone (CFZ) is the core of fishery arrangements in the Agreement. Fishery resources of the CFZ are shared, protected and managed by China and Vietnam. The CFZ is a considerable large co-management sea area. It locates in the EEZ of the two countries. As a result, China and Vietnam can apply domestic laws and regulations in their own side. Fishing vessels from China and Vietnam must meet 12 requirements if they intend to enter into the CFZ to operate fishing activities. ${ }^{65}$ For example, these vessels have to apply for fishing permits from their competent authorities of their own countries and need to be clearly marked. The fishermen have a duty to write the fishing logbook correctly and submit it to the competent authorities of their own countries within the prescribed time, in compliance with the Regulations set out by the JFC concerning fishing equipment, fishing methods and so on. The quantity of operating fishing vessels for each party in the CFZ was determined by the JFC annually, as mentioned above.

The special arrangements in the Transitional Arrangement Zone (TAZ) gave four years for each party to adjust their fishing patterns to the new and changed conditions by reducing fishing operations year by year. ${ }^{66}$ Consequently, China and Vietnam have enough time to offer educational and training programs to fishermen. At the end of the transitional arrangement, each party has the priority, under the same conditions, to operate fishing activities in the other's EEZ. ${ }^{67}$ Some scholars believed that the arrangement of gradual reduction of fishing vessels in the TAZ incorporated provisions for traditional fishing activities and represented the mutual recognition of both states' traditional fishing rights. ${ }^{68}$ Professor ZOU Keyuan believes that the transitional arrangements impliedly reflect the traditional fishing rights and can be seen as a partial realization of the Chinese traditional fishing rights in the Gulf. ${ }^{69} \mathrm{By}$ respecting the traditional fishing activities of the other party and

\footnotetext{
65 "Fishing vessels entering into the agreed water zones of the Beibu Gulf shall comply with 12 new rules (in Chinese)", News of Dayoo, last modified June 30, 2004, http://news.dayoo.com/china/gb/content/2004 -06/30/ content_1610612.htm.

${ }^{66}$ Article 11.1 of the Fishery Agreement.

${ }^{67}$ Article 11.3 of the Fishery Agreement.

${ }^{68}$ Huan-Sheng Tseng and Ching-Hsiewn Ou, "The evolution and trend of the traditional fishing rights,” Ocean \& Coastal Management 53 (2010): 276.

${ }^{69}$ ZOU Keyuan, "Sino-Vietnamese Fishery Agreement for the Gulf of Tonkin,” 17 International Journal of Marine \& Coastal Law 127 (2002): 139-140.
} 
postponing the application of EEZ's system to fishery management in the Gulf, an immediate impact on the livelihood and economy of their respective coastal fishermen was avoided. ${ }^{70}$

In addition to the CFZ and TAZ, the Fishery Agreement also sets up a Buffer Zone for small-scale fishing boats, which is not involving fishing activities. As the Buffer Zone is located in the territorial seas of China and Vietnam, in principle, fishing vessels of one party are prohibited from entering the other party's side, because the sovereignty of the coastal state must be respected. However, in view of the small-scale fishing vessels lack accurate locating devices and may illegally enter by mistake, each contracting party, if it finds that small fishing vessels of the other party conduct fishing activities in its own waters area, may send a warning, or take necessary measures to order them to leave its water area, but when so doing, the contracting party shall restrain its action not to detain or arrest the vessels in question, nor to impose punishment or use force against them. ${ }^{71}$ Any dispute relating to fishing activities within the Buffer Zone shall be reported to the Joint Fishery Committee for settlement.

\section{The Characteristics of the Fishery Arrangements in the Agreed Water Zones}

First, the distribution of the fishery resources between China and Vietnam is fair and reasonable as a whole. The CFZ and TAZ are located within parts of the EEZs of each party. The establishment of the agreed water zones takes into account the premise of maritime delimitation, and covers most of high yield fishing grounds in the Beibu Gulf. Thus, people of the two countries still can share most of the fishery resources. And following the principles of equality and mutual benefit, the quantity of fishing vessels operating fishing activities in the CFZ is equal for each party. The number of fishing vessels in each party's own zone of the TAZ has no much difference too. This kind of fishery arrangement ensures equality and mutual benefit, for this reason both parties would be more willing to comply with and perform the Agreement.

Second, the fisheries arrangements of the CFZ and the TAZ reflect the system of EEZ, which is stated in the $1982 \mathrm{UN}-$ CLOS. According to the UNCLOS, a coastal state has exclusive sovereign rights over managing fishery resources in the EEZ, including the competence to prescribe regulations in relation to fishery conservation and management, and the power to enforce these laws and regulations, especially on requiring foreign fishermen and fishing vessels to comply with the laws and regulations. ${ }^{72}$ Generally speaking, the competence of prescription can be divided into two kinds. The first kind relates to the prescription of conservation and management measures which may be applied to both national and foreign fishermen.

\footnotetext{
${ }^{70}$ Huan-Sheng Tseng and Ching-Hsiewn Ou, "The evolution and trend of the traditional fishing rights,” Ocean \& Coastal Management 53 (2010): 277; Nguyen Hong Thao and Ramses Amer, "Managing Vietnam's Maritime Boundary Disputes," Ocean Development \& International Law 38 (2007): 313; Ramses Amer and Nguyen Hong Thao, "Vietnam's Border Disputes: Legal and Conflict Management Dimensions,” 12 Asian Yearbook of International Law 111 (2005-2006): 121. In the latter two articles, the authors held the same idea that although the Beibu Gulf was_successfully demarcated but the application of the EEZ system to the fisheries regime was delayed in order to minimize the economic dislocation of the two States.

${ }^{71}$ Article 12.2 of the Fishery Agreement.

${ }^{72}$ Article 62.4 of the UNCLOS.
}

The second one concerns specifically the terms and conditions of foreign fishing vessels' access to the surplus of the living resources of the EEZ. ${ }^{73}$ At the same time, the coastal state may enforce the regulations for foreign vessels fishing in its EEZ by taking measures including boarding, inspection, arrest and judicial proceedings. ${ }^{74}$ Such a broad competence enables the coastal states to adopt the fishing management strategy best suited to its needs. ${ }^{75}$ Under the provisions of the UNCLOS, the Fishery Agreement provides that each party has jurisdiction over the nationals and fishing vessels of both parties in their own water areas of the CFZ and the TAZ, in line with the Fishery Regulations and domestic laws of China and Vietnam on preservation and management of fishery resources. ${ }^{76}$ In terms of domestic legislation, the Fisheries Law of China added new provisions that regulate nationals and fishing vessels of foreign countries. For instance, the Law prescribes that foreigners and foreign fishing vessels must obtain permission from the relevant competent departments prior to entering Chinese water to carry out fishing activities, and must observe Chinese laws and other relevant regulations. ${ }^{77}$ It also imposes legal liabilities on foreign fishermen and fishing vessels for violations. ${ }^{78}$ Similarly, the Law on Fisheries of Vietnam stipulates that those who commit acts of violating the provisions of this Law shall be administratively sanctioned or examined for penal liability; if causing damage, they must pay compensation according to the law provisions. ${ }^{79}$ The foreign fishing vessels entering to operate in Vietnam's seas must have fishery activities permits granted by competent Vietnamese State bodies and observe the relevant laws. If these vessels violate the laws and regulations, they shall be handled according to the provisions of Vietnamese laws. ${ }^{80}$

Third, adopting the principle of coastal state's jurisdiction instead of the principle of flag state control is a significant characteristic of the Fishery Agreement. "The EEZ regime has meant a move away from open access to resources and regulation based primarily on flag state jurisdiction, to near-exclusive coastal state access to resources and regulation based primarily-though not exclusive-on coastal state jurisdiction." ${ }^{81}$ As the maritime boundary has been clearly partitioned, the coastal state control shall apply within the EEZs of the coastal state. China also concluded fishery agreements with Japan and South Korea respectively. The Sino-Japanese Agreement and the Sino-South Korean Agreement applied the flag state control. Thus, if one state discovers a violation by the other party's vessels, it could only inform the flag state but not able to settle this violation immediately. And all matters regarding enforcement and punishment shall leave to the flag state. ${ }^{82}$ In this regard, some violations and illegal activities would not be dealt with timely or even escaped from punishment. Moreover, as a result of the flag state control, "even if joint monitoring and

\footnotetext{
${ }^{73}$ See M. Dahmani, The Fisheries Regime of the Exclusive Economic Zone (Dordrecht: Martinus Nijhoff Publishers, 1987), 82.

${ }^{74}$ Article 73 of the UNCLOS.

${ }^{75}$ R.R. Churchill and A.V. Lowe, The Law of the Sea (Third edition) (Manchester: Manchester University Press, 1999), 289.

${ }^{76}$ Article 9 of the Fishery Agreement.

${ }^{77}$ Article 8 of the Fisheries Law of China.

${ }^{78}$ Article 46 of the Fisheries Law of China.

${ }^{79}$ Article 58.1 of the Fisheries Law of Vietnam.

${ }^{80}$ Article 50 of the Law on Fisheries of Vietnam.

${ }^{81}$ R.R. Churchill and A.V. Lowe, The Law of the Sea (Third edition) (Manchester: Manchester University Press, 1999), 176.

${ }^{82}$ Nguyen Hong Thao, "Maritime Delimitation and Fishery Cooperation in the Tonkin Gulf,” Ocean Development \& International Law 36 (2005): 31.
} 
surveillance do take place, a law enforcement officer of one party would not be able to take an initiative role for its own enforcement purpose when he/she is on board a fishing vessel of the other party. So only an indirect form of co-operation in enforcement is possible." 83 On the contrary, the Sino- Vietnamese Fishery Agreement, based on the jurisdiction of the coastal state, provides that the competent authorities of the contracting parties have the right to monitor and inspect fishing activities, to impose punishment on the fishing vessels which enter its own water area in the CFZ without permission, or with permission but conduct illegal activities other than fishing activities. As a result, the abandonment of the "flag state control" doctrine ensures the compliance of fishermen and improves the effectiveness of the Agreement. ${ }^{84}$

Forth, fishery management is strict and complemented with comprehensive supporting measures. Article 7.1 of the Fishery Agreement stipulates explicitly that the contracting parties shall carry out the licensing system for fishing activities conducted by their own fishing vessels in the CFZ; fishing permits shall be issued in accordance with the quantity of fishing vessels in the current year determined by the JFC, and the names of the fishing vessels granted permits shall be notified to the other party. This provision is conducive not only to control the fishing intensity in the Common Fishery Zone and alleviate the fishing pressure, but also to law enforcement. In contrast, the SinoJapanese and the Sino-South Korean Fishery Agreement only provide that the competent authorities of the contracting parties may grant fishing permits to nationals and fishing vessels of the other party. ${ }^{85}$ Although the latter two also prescribe licensing system for fishing activities, they are very different from the Sino-Vietnamese Fishery Agreement in two aspects. First, the fishing license of the Sino-Vietnamese Fishery Agreement is clearly "limited". Neither China nor Vietnam can grant fishing permits exceeding the quantity which was determined at the annual meeting of the JFC. Second, the quantity of fishing licenses of the CFZ is not determined by the contracting parties, but by the JFC, while respecting to both parties, also limits their excessive discretion. At the same time, there are other corresponding measures to supplement the fishing license system. For example, under Article 7.2 of the Agreement, the contracting parties shall be obliged to educate and train their fishermen who conduct fishing activities in the Common Fishery Zone.

\section{Stable and Orderly Institutional Mechanism for Implementation}

According to the Fishery Agreement, the two parties established a Joint Fishery Committee to implement the Agreement. The JFC consists of two representatives respectively appointed by both parties and some committee members. It was authorized with a wide range of powers to deal with matters related to the conservation and management of fishery resources. It is to be noted that, in some extent, "the JFC has decisive power in handling all the issues regarding the bilateral co-operation.",86

\footnotetext{
${ }^{83}$ Sun Pyo Kim, "The UN convention on the law of the sea and new fisheries agreements in North East Asia,” Marine Policy 27(2003): 103.

${ }^{84}$ XUE Guifang, "Improved Fisheries Co-operation: Sino-Vietnamese Fisheries Agreement for the Gulf of Tonkin,” The International Journal of Marine and Coastal Law, 21 (2006): 228.

${ }^{85}$ Article 2.2 of the Sino-Japanese and the Sino-South Korean Fishery Agreement..

${ }^{86}$ XUE Guifang, "Improved Fisheries Co-operation: Sino-Vietnamese Fisheries Agreement for the Gulf of Tonkin,” The International Journal of Marine and Coastal Law 21 (2006): 224.
}

As we mentioned above, the JFC determines the quantity of fishing vessels of each party entering into the Common Fishery Zone annually. That is to say, it has the final decision on fishery production arrangement and the distribution of fishery resources. As for settlement of fishery disputes, the Fishery Agreement explicitly states that the JFC can settle those happened in the Buffer Zone. And according to the Fishery Regulations, fishery disputes which can not be settled on the scene, shall be solved by the executive agencies of the contracting parties, or submit to the JFC for settlement. ${ }^{87}$

The mechanism of decision-making of the JFC follows the principle of fairness and equality, stipulating that all the proposals and decisions of the JFC shall be subjected to consensus of the representatives of the contracting parties. It is very important that one party could not make its own decision on those issues related to fishery management but consult and cooperate with the other party. Through the mechanism of consultation of the JFC, China and Vietnam could exchange their views and notify each other promptly of the relevant circumstances and the way in which the issue has been handled. ${ }^{88}$

To fulfill its functions, the JFC did a lot of work, among which an important one is adopting the Fishery Regulations according to the Agreement. The Fishery Regulations prescribe the specific measures of conservation and management in the CFZ and the legal liabilities for violations. All nationals and fishing vessels shall comply with the Regulations. ${ }^{89}$ The allowable behaviors and forbidden behaviors are provided in detailed. By prescribing the legal liabilities of violations, both the fishermen and law enforcement officers would be able to expect for their behaviors and the consequences so that they would be more conscientious to obey the Agreement and the Regulations. We can say that most bilateral efforts were made by or with the help of the JFC. The smooth operation of the JFC is indispensable to the effective implementation of the Fishery Agreement.

Under the framework of the JFC, China and Vietnam also establish a talking mechanism for consultation and their own expert groups of fishery resources to provide assistance for implementation of the Fishery Agreement. ${ }^{90}$ The expert groups, as the wisdom tank of the JFC, deliver annual survey report of fishery resources to the JFC. On the basis of the reliable report, the JFC could make more rational and scientific decisions. With the institutional arrangements, the management of fishery resources was executed effectively in a relative stable way.

For any coastal state with a sizeable EEZ, proper enforcement of its fishery regulations in its EEZ presents a considerable challenge in terms of resources and technology. For developing countries these problems are particularly acute. ${ }^{91}$ Since both China and Vietnam are developing countries, there is an urgent need for these two countries to cooperate in monitoring and surveillance of fishing vessels by exchanging information and exploring the possibility of joint surveillance and

\footnotetext{
${ }^{87}$ Article 11 of the Fishery Regulations.

${ }^{88}$ XUE Guifang, "Improved Fisheries Co-operation: Sino-Vietnamese Fisheries Agreement for the Gulf of Tonkin," The International Journal of Marine and Coastal Law, 21 (2006): 226.

${ }^{89}$ Article 1 of the Fishery Regulations.

90"The implementation of the Sino-Vietnamese Fishery Agreement," China Fisheries News (in Chinese), June 7, 2010, p. 2; LI Yan, "Smooth Implementations of the Bilateral Fishery Agreements during the $11^{\text {th }}$ Five-year Plan,” China Fisheries News (in Chinese), June 20, 2011, p. 2.

${ }^{91}$ R.R. Churchill and A.V. Lowe, The law of the sea (Third edition) (Manchester: Manchester University Press, 1999), 293.
} 
reciprocal enforcement. To this end, based on their actual circumstances, China and Vietnam developed a cooperative mechanism in practice. For example, China and Vietnam established a steady mechanism to take joint monitoring and inspection, which is a development of the Agreement.

The joint monitoring and inspection reaffirms the efforts made by China and Vietnam to implement the Fishery Agreement and contributes to strengthening the mutual understanding of both sides. ${ }^{92}$ Through the joint inspection, the relevant departments of the two countries set up a good communication and coordination mechanism to carry out the law enforcement under the principle of reciprocity. The occurrence of illegal fishing and other crimes, such as armed robbery at sea, decreases dramatically, and most fishing vessels operate orderly and peacefully in the agreed water zones. In general, the joint inspection mechanism makes the joint enforcement become transparent, legal, and orderly, and also enhances mutual trust and understanding and reduces conflicts between China and Vietnam.

It is to be noted that effective fisheries management can eventually only be achieved if initial efforts in negotiation lead to a more permanent and structured framework for cooperation. ${ }^{93}$ Hence, the stable and orderly institutional arrangements, which take the JFC as the centre and couple with other cooperative mechanisms, are of extraordinary significance to effectively implement the Agreement.

\section{Comprehensive Law Enforcement with Moderate Restraint}

Enforcement is the process of invoking and applying authoritative prescriptions. ${ }^{94}$ It is designed to compel obedience to the rules. In the context of fisheries it means the process by which compliance by fishermen and fishing vessels with fisheries laws and regulations is ensured. This process involves two kinds of activities, which are preventive activities and activities refers to the means available to punish violations ${ }^{95}$ The range of preventive activities includes legal training and publicity, and the operation of surveillance, stopping and boarding vessels, search or inspection, reporting. The second kind involves arrest or seizure of fishermen and fishing vessels, detention, and formal application of law by judicial or other process, including imposition of sanctions. In the previous part, we have discussed about the measures taken by the contracting parties, which aimed at the furtherance of implementing the Fishery Agreement. These measures are comprehensive. For instance, China performed publicity of the Agreement and occupational training for fishermen, and established joint marine inspection mechanism both domestically and bilaterally with Vietnam, and so on.

China and Vietnam strive to minimize conflicts and tension and refrain themselves, as has been the prevailing policy of deal with bilateral relations between the two countries. ${ }^{96}$ Mutual

\footnotetext{
92“Vietnam, China inspect joint fishing area,” Ministry of Foreign Affairs of Vietnam, last modified February 10, 2007, http://www.mofa.gov.vn/en/nr 040807104143/nr040807105001/ns071001093343/view.

${ }^{93}$ Erik Jaap Molenaar, “The Concept of 'Real Interest' and Other Aspects of Co-operation through Regional Fisheries Management Mechanism,” 15 International Journal of Marine \& Coastal Law 475 (2000): 484.

${ }^{94}$ William T. Burke, The New International Law of Fisheries: UNCLOS 1982 and Beyond (New York: Oxford University Press, 1994), 303.

${ }^{95}$ M. Dahmani, The Fisheries Regime of the Exclusive Economic Zone (Dordrecht: Martinus Nijhoff Publishers, 1987), 83-84.

Ramses Amer and Nguyen Hong Thao, "Regional Conflict Management:

${ }^{96}$ Challenges of the Border Disputes of Cambodia, Laos, and Vietnam," Austrian Journal of South-East Asian Studies 2:2 (2009): 71.
}

restraint is especially emphasized in the Buffer Zone which requires the contracting parties restrain its action not to detain or arrest the small-scale vessels in question, nor to use force against them. Although the Fishery Agreement adopts the coastal state control in fishery management within the TAZ and CFZ, China and Vietnam showed self-restraints in dealing with foreign-related fishery disputes too. The Regulations require that public servants should be strictly implement law enforcement in accordance with the provisions of relevant laws and the Regulations, and not use force unless their personal safety is threatened. $^{97}$

China especially emphasizes the mutual restraint on the use of force in settling fishery conflicts with Vietnam. Mutual restraint of law enforcement is consistent with the stance of China that relevant countries should keep necessary self-restraint and avoid using of force in dealing with fishery disputes. ${ }^{98}$ Usually, China shows its sincerity and self-restraint when it dealt with illegal fishing acts which were conducted by foreign fishing vessels to avoid unnecessary conflicts. The normal methods that China often uses include observation, keeping records, expelling, boarding, and escorting. ${ }^{99}$ Depending on the severity, China gives different punishments. Fishing vessels conducting severe illegal activities will be seized or detained. The boats, fishing catches and tools will be confiscated, in addition to a fine. ${ }^{100}$ When the joint patrol team of China detects illegal fishing activities, the involved vessels will usually be punished with confiscation of catches and fishermen have to sign a guarantee of not conducting illegal actions again. If the illegal action is slight, the vessels will be only expelled out of Chinese sea areas. ${ }^{101}$

There was a Chinese case known as "The First Case". On August 22, 2004, law-enforcement officials of the fishery ad-

\footnotetext{
${ }^{97}$ Article 19 of the Fishery Regulations.

${ }^{98}$ China stated that only when the personal safety of the authorized inspecttors whose authorization has been duly verified is endangered and their normal inspecting activities are obstructed by violence committed by crew members of fishermen of the fishing vessel under inspection, may the inspectors take appropriate compulsory measures necessary to stop such violence. It should be emphasized that the action of force by the inspectors shall only be taken against those crew members or fishermen committing the violence and must never be taken against the vessel as a whole or other crew members or fishermen. See "Agreement for the Implementation of the Provisions of the United Nations Convention on the Law of the Sea of 10 December 1982 relating to the Conservation and Management of Straddling Fish Stocks and Highly Migratory Fish Stocks,” available at Division for Ocean Affairs and the Law of the Sea, last cheked November 23, 2012, http://www.un.org/Depts/los/convention_agreements/fish_stocks_agreement declarations.htm\#CHINA.

${ }^{\overline{99}}$ The information about the detainment and expelling the trespass and illegal fishing every year see: The Fisheries Bureau of Ministry of Agriculture, China Fisheries Yearbook (Beijing: China Agriculture Press, 2005) (in Chinese), 143; The Fisheries Bureau of Ministry of Agriculture, China Fisheries Yearbook (Beijing: China Agriculture Press, 2007) (in Chinese), 29; The Fisheries Bureau of Ministry of Agriculture, China Fisheries Yearbook (Beijing: China Agriculture Press, 2008) (in Chinese), 147; The Fisheries Bureau of Ministry of Agriculture, China Fisheries Yearbook (Beijing: China Agriculture Press, 2009) (in Chinese), 36.

100، The South China Sea disputes: how many reefs are there? - five years of implementation of the Sino-Vietnamese Delimitation Agreement,” Nanfang Weekend (in Chinese), last modified July 9, 2009, http://www.infzm.com/ content/31142; "Chinese Fishery Administration investigated and punished two Vietnamese Fishery Vessels with illegal behavior,” Yinzhou News (in Chinese), last modified April 21, 2012, http://yz.cnnb.com.cn/system/ 2012/04/21/010270988.shtml.

${ }^{101}$ "Chinese Fishery Administration and the Maritime Police held a joint marine patrol in the Chinese seas in the Beibu Gulf,” South China Sea Region Fisheries Administration Bureau (in Chinese), last modified July 8, 2009,
} 
ministration of China found 4 Vietnamese fishing boats without marking, operating fishing activities in Chinese sea area of the CFZ. The Chinese officers boarded the boats and took inspection. After investigation, the 4 Vietnamese fishing boats were verified of illegal fishing. They conducted fishing without legal fishing license, and illegally crossed the demarcation line by entering Chinese water. According to the Fishery Agreement and Chinese national law, Chinese fishery department made a decision on punishment: each ship shall be fined RMB 150,000 Yuan and all the catches shall be confiscated. In the execution of punishment, taking into account the practical difficulties of Vietnamese fishers, Chinese fishery department decided not to confiscate the net, and reduced the fine to RMB 125,000 Yuan. ${ }^{102}$

As for Vietnam, it also reacts in a similar way in some cases. Some Chinese fishermen said they feel much safer in the Beibu Gulf since the Fishery Agreement took effect. ${ }^{103}$ As Vietnamese scholar Nguyen Hong Thao explained that the principle of self-restraint has been proposed and well exercised by Vietnam in handling relations with other countries in the region of South China Sea. ${ }^{104}$

\section{The Positive Attitude of Dealing with Bilateral Relations}

After the entry into force of the Agreement, China and Vietnam constantly summarize and evaluate the implementation, and timely make necessary adjustments to improve their work. Both countries reiterated over and over again that they shall continue to cooperate closely, implement the Sino-Vietnamese Delimitation Agreement and the Fishery Agreement, actively explore the mode of joint marine patrol and inspection and the joint survey of fishery resources in the Beibu Gulf, and promote the establishment of a hotline between two countries fishery departments. ${ }^{105}$

They show their efforts to cooperate and develop a friendly relationship, and the commitments to reduce friction and increase mutual trust. In the Joint Statement between China and Vietnam (2011), the two States agreed to strengthen military cooperation by increasing contacts between high-ranking officers and establishing a hotline between their respective defense ministries. ${ }^{106}$ They also agreed to continue to hold joint marine patrols in the Beibu Gulf, and strengthen mutual visits and cooperation between their military warships. At the 5th meeting

\footnotetext{
102“Chinese Fishery Administration Investigated and Punished the Illegal Vietnamese Fishery Vessels for the First Time,” China Fisheries News (in Chinese), October 11, 2004, p. 1.

103 "The Fisheries Evolution of the Beibu Gulf: Employment of Vietnamese due to Labor Shortage,” in the World Wide Web (in Chinese), last modified May 23, 2012, http://china.huanqiu.com/border/2012-05/2747257.html.

${ }^{104}$ Nguyen Hong Thao, "Vietnam and the Code of Conduct for the South China Sea,” Ocean Development \& International Law 32 (2001): 117-118.

${ }^{105}$ See "Joint Statement between China and Vietnam(2011)," the Central People's Government of the People's Republic of China (in Chinese), last modified October 15, 2011, http://www.gov.cn/jrzg/2011-10/15/content_ 1970444.htm; "Joint Statement between China and Vietnam(2008)," Ministry of Foreign Affairs of the People's Republic of China (in Chinese), last modified October 25, 2008, http://www.fmprc.gov.cn/chn/pds/ziliao/zt/ ywzt/2008zt/dqjyosnhy/t528168.htm; “Joint Press Communiqué (2007),” Ministry of Foreign Affairs of the People's Republic of China (in Chinese), last modified July 18, 2007, http://www.fmprc.gov.cn/chn/gxh/wzb/zxxx/ t320502.htm,.

106،China, Vietnam agreed to strengthen military cooperation,” Reuters (in Chinese), last modified October 17, 2011,,http://cn.reuters.com/article/ wtNews/idCNCHINA-5059720111017.
}

of the Guiding Committee for Bilateral Cooperation between the two countries in September 2011, they reached agreements on many fields, including commitments to consolidate and develop their traditional good-neighborly friendship, to strengthen high-level communication and mutually beneficial cooperation in various fields, to properly handle sensitive issues and solve disputes. ${ }^{107}$

On $11^{\text {th }}$ October, 2011, China and Vietnam signed the "Agreement on basic principles guiding the settlement of maritime issues between the People's Republic of China and the Socialist Republic of Vietnam". This agreement has positive impacts on further preservation of fishery resources of the Beibu Gulf by reaffirming that the two countries shall cooperate in less sensitive fields, including marine environmental protection, scientific research, search and rescue, disaster reduction and prevention. Both sides also agreed to set up a hotline contact mechanism to allow them to promptly communicate and properly deal with maritime issues. ${ }^{108}$

It is not difficult to draw a conclusion that since the late 1990s, China and Vietnam have placed much importance on building good relations and continue to minimize tension caused and refraining from escalating it, as has been the prevailing policy of these two countries. ${ }^{109} \mathrm{By}$ doing so, the current mechanism of coordination and cooperation in fishery management has been consolidated.

\section{Main Problems and Suggestions for Improvement}

\section{Main Problems}

Firstly, the conservation measures are insufficient. As we all know, the fishery management not only deals with the exploitation of fishery resources, but also contains the conservation measures for fishery resources. By reviewing the Fishery Agreement and its implementing practice, we can say that the current mechanism of fishery management in the Beibu Gulf pays too much attention to the exploitation and utilization of fisheries, and leaves little room to the conservation. There are only a few provisions involving the conservation measures in the Fishery Agreement. Although the Joint Fishery Committee adopted the Fishery Regulations which contains some particular provisions on conservation, in practice, too few measures in relation to conservation of fishery resources were taken jointly by both contracting parties. Similarly, although the Fishery Agreement imposes an obligation on the contracting parties to cooperate in scientific research for fisheries. ${ }^{110}$ The two States gave little response in the bilateral cooperation except the joint surveys of fishery resources and some small-scale proliferation activities.

\footnotetext{
107، The 5th meeting of the Guiding Committee for bilateral cooperation between China and Vietnam was held in Hanoi," Sohu News (in Chinese), last modified September 6, 2011, http://roll.sohu.com/20110906/n3185612 92.shtml.

${ }^{108}$ See "Agreement on Basic Principles Guiding the Settlement of Sea Issues between Vietnam and China," The Central People's Government of the People's Republic of China (in Chinese), last modified October 12, 2012, http://www.gov.cn/jrzg/2011-10/12/content_1966682.htm

${ }^{109}$ Ramses Amer and Nguyen Hong Thao, "Regional Conflict Management: Challenges of the Border Disputes of Cambodia, Laos, and Vietnam," Austrian Journal of South-East Asian Studies 2 (2009): 70-71.

${ }^{110}$ Article 17 of the Fishery Agreement imposes an obligation of that the contracting parties shall cooperate for fishery scientific research and preservation of marine living resources in the agreed water zones.
} 
Secondly, the Fisheries Regulations stipulates that China and Vietnam shall carry out a fishing ban in the CFZ, and the implementation measures will be set down by the JFC. ${ }^{111}$ However, the provision of fishing ban has not been executed very well in practice. China conducted the fishing ban in the Chinese sea areas in the South China Sea (including parts of the Beibu Gulf) since 1999 and received some positive results. The practice has proved that fishing ban plays a great role in promoting and restoring the fishery resources. ${ }^{112}$ However, the positive achievements are difficult to maintain. As many fish species are migratory stocks, they do not care about the political boundaries made by human beings. Therefore the two States must cooperate to conserve and protect the fishery resources. But no corresponding efforts have ever made by the Vietnamese side. ${ }^{113}$ Even worse, Vietnam has vociferously protested for the Chinese fishing ban by arguing that it affects the livelihood of Vietnamese fishermen. ${ }^{114}$ It is a fact that when the Chinese fishers observe the fishing ban, Vietnamese fishers still conduct fishing activities in the agreed water zones. ${ }^{115}$ Some Chinese scholars were dissatisfiedly pointed out that such uncooperative behaviors would certainly do harm to fishery management and the relationship between the two countries. ${ }^{116}$

Thirdly, what is very worrying is overexploitation of the fishery resources. The current situation of fishery resources of the Beibu Gulf is not so hopeful. The fact that excess fishing capacity is one of the leading causes of overfishing has been widely recognized. ${ }^{117}$ In the 9th meeting of the Joint Fishery Committee in 2012, the Chinese government pointed out that there is a recessionary and over-exploited trend of fishery resources in the Vietnamese side of the Common Fishery Zone, for the raising number of large fishing vessels of Vietnam. In regard to Vietnam, within its municipal fishery, entry of fishing activities is not restricted except for certain imposed requirements, such as licensing of boats, although payment is minimal. Uncontrolled entry into the fishing sector could lead to overexploitation of the resources. ${ }^{118}$ In addition, as the government of

\footnotetext{
${ }^{111}$ Article 7 of the Fishery Regulations.

${ }_{112}^{11}$ Article 7 of the Fishery Regulations.
Fisheries Bureau of Ministry of Agriculture: the summer fishing ban has been executed for 15 years and brings remarkable results,” the Central People's Government of the People's Republic of China (in Chinese), last modified November 19, 2009, http://www.gov.cn/gzdt/2009-11/19/content_ 1468595.htm.

${ }^{113}$ ZOU Keyuan, "Sino-Vietnamese Fishery Agreement for the Gulf of Tonkin,” 17 International Journal of Marine \&Coastal Law 127 (2002): 131; Katharina Schlick, "Fishery agreements in view of the South China Sea Conflict: A regional cooperative approach to maritime resource conflicts and territorial disputes," China Papers 19 (2009): 6 (New Zealand Contemporary China Research Centre: http://www.victoria.ac.nz/chinaresearchcentre, China Papers is a programme of regular publication of working papers by the New Zealand Contemporary China Research Centre).

${ }^{114}$ Leszek Buszynski, “The South China Sea: Oil, Maritime Claims, and U.S.-China Strategic Rivalry,” The Washington Quarterly 35:2 (2012): 143.

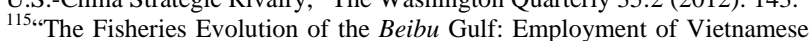
due to Labor Shortage," in the World Wide Web (in Chinese), last modified May 23, 2012, http://china.huanqiu.com/border/2012-05/2747257.html; "The South China Sea disputes: how many reefs are there? - five years of implementation of the Sino-Vietnamese Delimitation Agreement,” Nanfang Weekend (in Chinese), last modified July 9, 2009, http://www.infzm.com/ content/31142..

${ }^{116}$ WU Zhi-de and ZOU Jian-wei and FU De, "Problems and countermeasures of implementing summer fishing closure season in Guangxi Province," Chinese Fisheries Economics (in Chinese) 2 (2009): 16.

${ }^{117}$ Robert Pomeroy et al., "Fish wars: Conflict and collaboration in fisheries management in Southeast Asia,” Marine Policy 31(2007): 645.

${ }^{118}$ M.M.M. Pho Hoang Han, "Fisheries development in Vietnam: A case study in the exclusive economic zone,” Ocean \& Coastal management 50 (2007): 706.
}

Vietnam encourages migration to coastal areas and the expansion of the fisheries sector, the labor population involved fishery industry of Vietnam will be probably growing and affecting the sustainable fishery resources uses. ${ }^{119}$

All above problems remind us that much work still needs to be done in order to effectively conserve and manage and sustainably utilize the fishery resources in the Gulf.

\section{Suggestions for Improvement}

\section{Control Fishing Capacity at a Rational Level}

The fishery resources of the Beibu Gulf are under great pressure of over-exploitation now. The pressure of fishing stands still and China and Vietnam must take actions to control overfishing and manage the fishing capacity. ${ }^{120}$ Firstly, to implement double control over fishing vessels and the power amount of fishing boats. Vessels without legal certificates or exceeding the useful life shall be eliminated from fishing operation. This measure bases on reliable data resulted from surveys on fishery resources and scientific research. Secondly, to provide more occupational training opportunities. Most fishermen are less educated and have rare other working skills except fishing. Even though the fishermen are willing to leave fishing sector, they could not easily find another job because lack of skills. Hence the government of each party should provide more opportunities of education and training for their interested fishermen. At the same time, the government shall adjust the structure of fishery industry and increase more working opportunities in other industrial fields to transfer surplus fishing labor. Some relevant industries could be considered to develop, such as aquaculture, aquatic products processing industry, leisure tourism and service industry, and transportation industry. ${ }^{121}$

\section{Carry out More Effective Joint Fishing Ban}

Now, the effectiveness of the fishing ban of China is questioned by some critics from China ${ }^{122}$, Vietnam or other countries. Some scholars have questioned the rationality and legitimacy of the Chinese fishing ban by arguing that the extent of the ban was kept too vague. ${ }^{123}$ And some pointed out that the recovery of fish stocks from the fishing ban has not been as great as predicted due to some negative impacts. ${ }^{124}$ Even those scholars, who appreciate that the fishing ban might have a posi-

\footnotetext{
${ }^{119}$ Jesper Raakjar et al., “Adaptive fisheries management in Vietnam: The use of indicators and the introduction of a multi-disciplinary Marine Fisheries Specialist Team to support implementation,” Marine Policy 31(2007): 144; Nopparat Nasuchon, "Coastal management and community management in Malaysia, Vietnam, Cambodia and Thailand, with a case study of Thai fisheries management," Division for Ocean Affairs and the Law of the Sea Office of Legal Affairs, the United Nations, New York, 2009, 25. last checked November 1, 2012, http://www.un.org/depts/los/nippon/unnff_programme_home/fellows_pages/fellows_papers/nasuchon_0809_thailand.pdf.

${ }^{120}$ CUI Lifeng, "Adapt to the new ocean legal system and promote the healthy development of marine fisheries -- in commemoration of the 30th anniversary of signing the United Nations Convention on the Law of the Sea," China Fisheries News (in Chinese), September 24, 2012, p. 1.

${ }^{121}$ HUANG shuolin and GUO wenlu, Disputes and Research on the Regional Cooperation and Management of Fishery Resources in the South China Sea (Beijing: Ocean Press, 2007) (in Chinese), 174.

${ }^{122}$ Zuozhi CHEN, Shannan XU, Yongsong QIU, Zhaojin LIN and Xiaoping JIA, "Modeling the effects of fishery management and marine protected areas on the Beibu Guf using spatial ecosystem simulation,” Fisheries Research 100 (2009): 227.

${ }^{123}$ Leszek Buszynski, "The South China Sea: Oil, Maritime Claims, and U.S.-China Strategic Rivalry,” The Washington Quarterly 35 (2012): 143.

${ }^{124}$ Huiguo YU and Yunjun YU, "Fishing capacity management in China: Theoretic and practical perspectives,” Marine Policy 32 (2008): 354.
} 
tive result of contribution to the protection of fishery resources, still argue that its biggest flaw is to create high tension with the other country if it is applied unilaterally. ${ }^{125}$ It is doubtless that the fishing ban needs further improvement, like adjustment of its executing time and the banned types of fishing vessel and fishing method. But practice has proved that this measure is necessary and effective to promote the sustainability of marine living resources in the Beibu Gulf and prevent overfishing. It is an effective measure to protect fishery resources. The population of natural fish stocks both in marine and freshwater has been successfully re-established since the implementation of the fishing ban, and thereby maintaining the sustainability and affordability of fisheries. ${ }^{126}$ A survey of fishing ban in Guangxi Autonomous Zone has shown us some good outcomes. It was pointed out in the Working Conference on the Summer Fishing Ban in the Region of the South China Sea in 2010, that the fishing ban in the region had a successful adjustment, and the rehabilitation of fishery resources in the South China Sea had made more significant effects, which had postponed the recession of fishery resources in the South China Sea greatly. Effective conservation and recovery of some certain fishery stocks had been made, and the development of marine fishing had been maintained. Fishing catch increased significantly in the main fishing grounds, among which the average fishing catch in the Beibu Gulf increased by $296.7 \% .{ }^{127}$ What's more, compared with other measures, the fishing ban is a relatively lower cost measure, because "to declare an area closed to fishing in a particular closed season may be easily monitored and controlled"128. And to implement a fishing ban is required by the Fishery Regulations, which explicitly provides that the contracting parties shall set up a joint fishing ban in the Common Fishery Zone. ${ }^{129}$ Here, the key point is that China and Vietnam should do more scientific research on the fishing ban, cooperate with each other and exchange relevant data and information to improve it. It is obvious that fishery resources could not be protected and conserved effectively by unilateral actions.

Take Measures of Proliferation and Placing Artificial Reefs

Artificial reef construction is an important measure to repair the coastal ecological environment, to increase and protect the fishery resources. ${ }^{130}$ In the last century, Japan, Britain, the US and Germany all placed artificial reefs to protect the fisheries' habitat and got economic and biologic benefits. By placing artificial reefs in the sea areas, the habitat of fish was improved and of great help to promote conservation and development of fishery resources. As we mentioned above, in recent years, the coastal provinces of China also have organized many large-

\footnotetext{
${ }^{125}$ Hai-Dang Vu, “A Bilateral Network of Marine Protected Areas between Vietnam and China: An Alternative to the Chinese Unilateral Fishing Ban in the South China Sea?” last checked October 25, 2012, http://nghiencuubiendong.vn/ download/doc_download/505-vu-hai-dang-a-bilateral-network-of-marine-protect-ted-areas-between-vietnam-and-china-an-alternative-to-the-chinese-unilateral- fishing-ban-in-the-south-china-sea.

${ }^{126}$ Duo LI and Xiaojie HU, "Fish and its multiple human health effects in times of threat to sustainability and affordability: are there alternatives?" Asia Pacific Journal of Clinical Nutrition18 (2009): 556.

${ }^{127}$ YUAN Lin and BI Chaobin, "Obvious Effect on Fishery Resources Rehabilitation in the South China Sea," Guangxi Daily (in Chinese), April 26, 2010, 4.

${ }^{128} \mathrm{M}$. Dahmani, The fisheries regime of the exclusive economic zone (Dordrecht: Martinus Nijhoff Publishers, 1987), 87.

${ }^{129}$ Article 7 of the Fishery Regulations.

${ }^{130}$ QIU Yongsong, ZENG Xiaoguang, CHEN Tao, WANG Yuezhong and YUAN Weiwen, The fishery resources and fishery management in the South China Sea (Beijing: Ocean Press, 2008), (in Chinese), 226.
}

scale marine living resources proliferation actions. Through proliferation, Chinese people enhance the awareness of protection of fishery resources, and an atmosphere of caring and protecting environment and resources is created in the whole society. However, joint efforts from both contracting parties need more. As the fishery resources in the Beibu Gulf are shared by the two neighboring countries, they should share the responsebilities and obligations of conservation and protection too. People have a clear unanimity on one point that fisheries can be sustainable if the stocks are allowed to recover and if more sensitive management practices are put in pace. ${ }^{131}$

\section{Seek More Financial Support and Minimize the Cost}

Notably, financial support is indispensable for the effective implementation of the Fishery Agreement. For example, surveillance and control equipment, such as surveillance vessels and aircraft, is need of increase. As we all know, "to improve fisheries managements requires not only the reduction or elimination of over-capacity but also better scientific knowledge of fish stocks and the marine ecosystem generally, as well as better conduits for the transmission of scientific advice, less tainted by political considerations, to fishery managers.”132 Without adequate money, the mechanism of fishery management could not be operated well. In order to get more financial support, some scholars suggest introducing a mechanism of multi-sources investment. Some even suggest that besides increasing the financial support of government, the fishery Industry shall bear a portion of the cost of the activities of licensing, data collection, stocks assessment, monitoring and enforcement, for it benefits from those activities. ${ }^{133}$ However, it is important to bear in mind that any cooperative actions shall not impose too heavy a financial burden on States. Joint efforts must be made to reduce the cost of cooperation to the minimum and take into account the financial capacity of concerned countries. Otherwise, States might be unwilling to take such cooperative actions. For most developing countries, the problem of enforcement cost is much more severe in consideration of their insufficient financial capacity. These developing countries have more or less financial difficulties to acquire surveillance and control equipment, and to develop the technological, administrative and scientific capacities necessary for the law enforcement. China and Vietnam are also facing such dilemma. Therefore, when China and Vietnam formulate a system of fishery management, they should endeavor to strike a balance between the cost factor and the effectiveness of the system. That is to say, "to adopt laws and regulations that can ensure the maximum protection for the fisheries resources but can be enforced without too much cost". 134

\section{Conclusion}

The Fishery Agreement provides the legal basis for China and Vietnam to cooperate on management, conservation and utilization of the fishery resources in the EEZs in the Beibu

\footnotetext{
${ }^{131}$ Alan Longhurst, “The sustainability myth,” Fisheries Research 81(2006): 107.

${ }^{132}$ R.R. Churchill and A.V. Lowe, The law of the sea (Third edition) (Manchester: Manchester University Press, 1999), 322.

${ }^{133}$ Daniel E. Lane and Robert L. Stephenson, "Institutional arrangements for fisheries: alternate structures and implediments to change,” Marine Policy 24 (2000): 392.

${ }^{134} \mathrm{M}$. Dahmani, The fisheries regime of the exclusive economic zone (Dordrecht: Martinus Nijhoff Publishers, 1987), 87.
} 
Gulf. The Agreement has established a long-term cooperative mechanism to manage the fishery resources. Since China and Vietnam signed the Fishery Agreement, they have taken a lot of measures to implement it, both in bilateral and unilateral levels to manage and conserve the fishery resources in the Gulf. Generally speaking, the Agreement's implementation has produced numerous positive results for the two states: cooperation between them is strengthened and fishery conflicts are significantly reduced; the fishery resources are shared and exploited peacefully and fairly, and the relationship between China and Vietnam in the Beibu Gulf becomes stable and orderly. Compared with implementing the Sino-Japanese Fishery Agreement and the Sino-South Korean Fishery Agreement, ${ }^{135}$ Sino-Vietnamese Fishery Agreement has gone quite smoothly. It is worth summarizing the successful experience of implementing the Agreement in the Beibu Gulf which provides costal States with an example or model of fishery cooperation in EEZ under UNCLOS.

It cannot be denied that problems still exist in the current fishery management of the Beibu Gulf for which the contracting parties concerned should face and take seriously. China and Vietnam need to do more in the future.

\section{Acknowledgements}

This research is funded by the Philosophy and Social Science Cultivation Project of Sun Yat-sen University on the Innovation Research Group (Project No. 12000-3281901).

\section{REFERENCES}

Amer, R., \& Thao, N. H. (2005-2006). Vietnam's border disputes: Legal and conflict management dimensions. Asian Yearbook of International Law, 12, 111-127.

Amer, R., \& Thao, N. H. (2009). Regional conflict management: Challenges of the border disputes of Cambodia, Laos, and Vietnam. Austrian Journal of South-East Asian Studies, 2, 53-80.

Armitage, D., Marschke, M., \& Tuyen, T. (2011). Early-stage transformation of coastal marine governance in Vietnam? Marine Policy, 35, 703-711. doi:10.1016/j.marpol.2011.02.011

The Central People's Government of the People's Republic of China, (2011). Agreement on Basic Principles Guiding the Settlement of Sea Issues between China and Vietnam.

http://www.gov.cn/jrzg/2011-10/12/content_1966682.htm

United Nations, (2012). Agreement for the implementation of the provisions of the United Nations Convention on the law of the sea of 10 December 1982 relating to the conservation and management of straddling fish stocks and highly migratory fish stocks.

http://www.un.org/Depts/los/convention_agreements/fish_stocks_agr eement_declarations.htm\#CHINA

Ablan, M., Carmen, A., \& Garces, L. R. (2012). Exclusive economic zones and the management of fisheries in the South China Sea. In A. Syma Ebbin, A. H. Hoel, \& A. K. Sydnes (Eds.), A sea change: The exclusive economic zone and governance institutions for living marine resources (pp.136-149).

http://link.springer.com/chapter/10.1007/1-4020-3133-5_9\#page-1

Burke, W. T. (1994). The new international law of fisheries: UNCLOS

\footnotetext{
${ }^{135}$ It seems that implementing the fishery agreements come up against problems in the East China Sea. In recent years there are a number of serious conflicts between China and Japan, China and South Korea, especially with the latter. The severe fishery conflicts between China and South Korea in recent years are listed in this report: "More Fishery Conflicts between P. R. China and the South Korea: Excessive Enforcement of the South Korea Added fuel to the flames," Ifeng News, last modified October 17, 2012. http://news.ifeng.com/world/detail_2012_10/17/18319756_0.shtml
}

1982 and beyond. New York: Oxford University Press.

Buszynski, L. (2012). The South China sea: Oil, maritime claims, and US-China strategic rivalry. The Washington Quarterly, 35, 139-156. doi:10.1080/0163660X.2012.666495

Churchill, R. R., \& Lowe, A. V. (1999). The law of the sea (3rd edition). Manchester: Manchester University Press.

Zhang, G. T., \& Lin, S. (204). Chinese Fishery Administration Investigated and Punished the Illegal Vietnamese Fishery Vessels for the First Time (in Chinese). China Fisheries News, October 11, 2004, 1.

The Fisheries Administration Bureau of South China Sea Region (2007). Concentration on the Annual Propaganda and Popularization of the Fishery Law in the Region of the South China Sea. http://www.moa.gov.cn/sydw/nhyzj/gzdt/200712/t20071206_211067 3.htm

Cinner, J. E., \& Aswani, S. (2007). Integrating customary management into marine conservation. Biological Conservation, 140, 201-216. doi:10.1016/j.biocon.2007.08.008

Chinese Fishery Administration and the Maritime Police held a joint marine patrol in the Chinese seas in the Beibu Gulf (2009). http://www.moa.gov.cn/sydw/nhyzj/xwjj/200907/t20090708_211093 3.htm

Chen, Z. Z., Xu, S. N., Qiu, Y. S., Lin, Z. J., \& Jia, X. P. (2009). Modeling the effects of fishery management and marine protected areas on the Beibu Guf using spatial ecosystem simulation. Fisheries Research, 100, 222-229. doi:10.1016/i.fishres.2009.08.001

Cheng, F. (2011). China and Vietnam agreed to strengthen military cooperation (in Chinese). http://cn.reuters.com/article/wtNews/idCNCHINA-5059720111017

Foreign Handling Office of Jiangsu Province (2012). China and Vietnam strengthen fishery cooperation in the Beibu Gulf (in Chinese). http://www.jsof.gov.cn/art/2012/9/3/art_131_107323.html.

Yinzhou News (2012). Chinese fishery administration investigated and punished two vietnamese fishery vessels with illegal behavior (in Chinese).

http://yz.cnnb.com.cn/system/2012/04/21/010270988.shtml.

Cui, L. F. (2012). Adapt to the new ocean legal system and promote the healthy development of marine fisheries: In commemoration of the 30th anniversary of signing the United Nations Convention on the Law of the Sea (in Chinese). China Fisheries News, September 24, 2012.

Dahmani, M. (1987). The fisheries regime of the exclusive economic zone. Dordrecht: Martinus Nijhoff Publishers.

The Government of Vietnam (2012). Decree on regulations on penalizing administrative violations in the fisheries field. http://moj.gov.vn/vbpq/en/_layouts/printeng.aspx?id=10619.

The Government of Vietnam (2012). Decree on management of fisheries activities of foreign ships in Vietnam's sea areas. http://vietnam.vn/decree-on-management-of-fisheries-activities-of-fo reign-ships-in-vietnams-sea-areas-c1071n20111129151457953.htm

Fisheries Bureau of Ministry of Agriculture (2004). Emergent circular on the preparation of implementing the Sino-Vietnamese fishery agreement (in Chinese).

http://www.moa.gov.cn/zwllm/zxfb/201007/t20100702_1592501.htm

Yao R. F. (2004). Fishing vessels entering into the agreed water zones of the Beibu Gulf shall comply with 12 new rules (in Chinese). http://news.dayoo.com/china/gb/content/2004-06/30/content_161061 2.htm

Huang Z. P. (2006). For the peace and harmony of the Beibu Gulf (in Chinese).

http://www.moa.gov.cn/sydw/nhyzj/gzdt/200609/t20060928_211080 6.htm

Ling, W. M. (2011). Fisheries of the Beibu Gulf are in stable order (in Chinese).

http://www.ysfri.ac.cn/Newshow.asp-showid=1881\&signid=25.htm

Ministry of Fisheries and the World Bank (2005). Final Report of Fisheries and Aquaculture Sector Study of Vietnam.

http://siteresources.worldbank.org/INTVIETNAM/Resources/vn_fis heries-report-final.pdf

General Office of the People’s Government of Hainan Province (2004). An emergent notice on making a good preparation for the implementation of the Sino-Vietnamese fishery agreement which will take 
effect soon (in Chinese).

http://china.findlaw.cn/fagui/jj/25/110604.html

Gui, S. (2010). Guangxi Issues emergency plans for foreign-related fishing (in Chinese). China fisheries news, 15 November 2010, 2.

The Fisheries Administration Bureau of China (2011). Guangxi obtains good results from escorting action and marine patrol in the EEZ in 2011 (in Chinese).

http://www.moa.gov.cn/sjzz/yzjzw/yyzfyzj/zhyyzf/201112/t2011120 9_2717509.htm

The Fisheries Administration Bureau of South China Sea Region (2006). Hainan Province attaches great importance to the training work for foreign-related fishing crew (in Chinese).

http://www.moa.gov.cn/sydw/nhyzj/gzdt/200608/t20060807_2110822. htm.

Pho Hoang Han, M. M. M. (2007). Fisheries development in Vietnam: A case study in the exclusive economic zone. Ocean \& Coastal management, 50, 699-712. doi:10.1016/j.ocecoaman.2002.06.001

Ministry of Foreign Affairs of the People's Republic of China (2007). Joint Press Communiqué (in Chinese).

http://www.fmprc.gov.cn/chn/gxh/wzb/zxxx/t320502.htm

Ministry of Foreign Affairs of the People's Republic of China (2008). Joint statement between China and Vietnam (in Chinese). http://www.fmprc.gov.cn/chn/pds/ziliao/zt/ywzt/2008zt/dqjyosnhy/t5 28168.htm

The Central People's Government of the People's Republic of China (2011). Joint statement between China and Vietnam (in Chinese).

http://www.gov.cn/jrzg/2011-10/15/content_1970444.htm

Kim, S. P. (2003). The UN convention on the law of the sea and new fisheries agreements in north East Asia. Marine Policy, 27, 97-109. doi:10.1016/S0308-597X(02)00082-9

Lane, D. E., \& Stephenson, R. L. (2000). Institutional arrangements for fisheries: Alternate structures and impediments to change. Marine Policy, 24, 385-393. doi:10.1016/S0308-597X(00)00014-2

Longhurst, A. (2006). The sustainability myth. Fisheries Research, 81, 107-112. doi:10.1016/j.fishres.2006.06.022

Liu, Y. (2009). The five years of the implementation of the fishery agreement: Interview of Wu Zhuang, Director of the South China Sea Fisheries Administration Bureau of Ministry of Agriculture (in Chinese). China Fisheries, 7, 4-6.

Li, D., \& Hu, X. (2009). Fish and its multiple human health effects in times of threat to sustainability and affordability: Are there alternatives? Asia Pacific Journal of Clinical Nutrition, 18, 553-563.

Law on Fisheries of Vietnam. (2010).

http://caexpo.gxciq.gov.cn/html/2010-11/98.htm

Liang, Z. (2011). Hainan yearbook (in Chinese). Haikou: Hainan Yearbook Press.

Ifeng News (2012) More fishery conflicts between P. R. China and the South Korea: Excessive enforcement of the South Korea added fuel to the flames. (2012).

http://news.ifeng.com/world/detail_2012_10/17/18319756_0.shtml

Nasuchon, N. (2009). Coastal management and community management in Malaysia, Vietnam, Cambodia and Thailand, with a case study of Thai fisheries management. Division for Ocean Affairs and the Law of the Sea Office of Legal Affairs, the United Nations, New York.

http://www.un.org/depts/los/nippon/unnff_programme_home/fellows _pages/fellows_papers/nasuchon_0809_thailand.pdf

Pomeroy, R., Parks, J., Pollnac, R., Campson, T., Genio, E., Marlessy, C., et al. (2007). Fish wars: Conflict and collaboration in fisheries management in Southeast Asia. Marine Policy, 31, 645-656. doi:10.1016/j.marpol.2007.03.012

The Fisheries Administration Bureau of South China Sea Region (2008). Proliferation of living resources of the Beibu Gulf was held in Beihai City (in Chinese).

http://www.moa.gov.cn/sydw/nhyzj/gzdt/200806/t20080616_211061 3.htm.

Qiu, Y., Zeng, X., Chen, T., Wang, Y., \& Yuan, W. (2008). The fishery resources and fishery management of the South China Sea (in Chinese). Beijing: Ocean Press.

Raakjar, J., Son, D. M., Stæhr, K.-J., Hovgård, H., Thuy, N. T. D.,
Ellegaard, K., et al. (2007). Adaptive fisheries management in Vietnam: The use of indicators and the introduction of a multi-disciplenary marine fisheries specialist team to support implementation. Marine Policy, 31, 143-152. doi:10.1016/j.marpol.2006.05.013

Fisheries Administration Command Center of Ministry of Agriculture (2009). Regulation on administrative law enforcement of fisheries inspection.

http://www.chinalawedu.com/new/1200_22016

/2009_6_2_li441 719255012690024669.shtml

Schlick, K. (2009). Fishery agreements in view of the South China Sea Conflict: A regional cooperative approach to maritime resource conflicts and territorial disputes. China Papers, No. 19.

http://www.victoria.ac.nz/chinaresearchcentre.

Thao, N. H. (2001). Vietnam and the code of conduct for the South China Sea. Ocean Development \& International Law, 32, 105-130. doi:10.1080/00908320151100244

Thao, N. H. (2005). Maritime delimitation and fishery cooperation in the Tonkin Gulf. Ocean Development \& International Law, 36, 2544. doi:10.1080/00908320590904939

Thao, N. H., \& Amer, R. (2007). Managing Vietnam's maritime boundary disputes. Ocean Development \& International Law, 38, 305-324. doi:10.1080/00908320701530482

Tønnesson, S. (2003). Sino-Vietnamese rapprochement and the South China Sea irritant. Security Dialogue, 34, 55-70.

Tseng, H.-S., \& Ou, C.-H. (2010). The evolution and trend of the traditional fishing rights. Ocean \& Coastal Management, 53, 270-278. doi:10.1016/j.ocecoaman.2010.02.002

Thang, N. D. (2012). Fisheries cooperation in the South China Sea and the (Ir)relevance of the sovereignty question. Asian Journal of International Law, 2, 59-88. doi:10.1017/S2044251311000099

The General Office of Ministry of Finance of the People's Republic of China and The General Office of Ministry of Agriculture of the People's Republic of China (2003). The regulations on management of using special fund for fisherman who change their jobs (in Chinese). http://www.moa.gov.cn/sjzz/yzjzw/fzghyzj/xmdtfzgh/200311/t20031 105_2676486.htm

Fisheries Bureau of Ministry of Agriculture (2004). The Standing Committee of the National People's Congress. The Fisheries Law of China.

http://www.fdi.gov.cn/pub/FDI_EN/Laws/GeneralLawsandRegulatio ns/BasicLaws/t20060620_50950.jsp

The Ministry of Agriculture of China issues the circular on implementing the Sino-Vietnamese Fishery Agreement (in Chinese). (2004). http://www.jincao.com/fa/25/law25.93.htm

The Office of People's Government of Beihai of Guangxi Province (2004). A Notice on the Implementation Program of the Sino-Vietnamese Fishery Agreement issued by the Beihai Aquatic Products Bureau (in Chinese).

http://www.law-lib.com/law/law_view.asp?id=146449

General Office of the State Council, (2004). The circular of the General Office of the State Council on Strengthen- ing the Administration of Foreign-related Fishing Activities. http://www.lawinfochina.com/display.aspx?lib=law\&id=3713\&payc ode=43B0D2C5DD0BCF700B163F2B0BC078A239848666E049F4 051FDF297F7B7AB43E\#

Dong, J. (2005). The Ministry of Agriculture of China urges relevant coastal provinces to formulate fishing vessels scrapping programs to control fishing capacity.

http://news.163.com/50104/3/197K5IUG0001124T.html

The Fisheries Administration Bureau of South China Sea Region (2006). Training work for foreign-related fishing crew of Guangxi is fully underway (in Chinese).

http://www.moa.gov.cn/sydw/nhyzj/gzdt/200607/t20060727_2110829. htm

The Fisheries Administration Bureau of South China Sea Region (2007). The sixth Sino-Vietnamese joint survey of fishery resources of the Beibu Gulf was completed (in Chinese).

http://www.moa.gov.cn/sydw/nhyzj/gzdt/200705/t20070511_2110751. htm

The Fisheries Bureau of Ministry of Agriculture. (2005). China fisher- 
ies yearbook (in Chinese). Beijing: China Agriculture Press.

The Fisheries Bureau of Ministry of Agriculture. (2007). China fisheries yearbook (in Chinese). Beijing: China Agriculture Press.

The Fisheries Bureau of Ministry of Agriculture. (2008). China fisheries yearbook (in Chinese). Beijing: China Agriculture Press.

The Fisheries Bureau of Ministry of Agriculture. (2009). China fisheries yearbook (in Chinese). Beijing: China Agriculture Press.

The Fishery Bureau of the Ministry of Agriculture. (2010). China fisheries yearbook (in Chinese). Beijing: China Agriculture Press.

The Fishery Bureau of the Ministry of Agriculture. (2011). China fisheries yearbook (in Chinese). Beijing: China Agriculture Press.

The Fisheries Bureau of Ministry of Agriculture: The summer fishing ban has been executed for 15 years and brings remarkable results (in Chinese). (2009).

http://www.gov.cn/gzdt/2009-11/19/content_1468595.htm

The Fisheries Administration Bureau of South China Sea Region (2009).The eleventh meeting of Sino-Vietnamese expert groups of fishery resources of the Beibu Gulf held in Guangzhou (in Chinese). http://www.moa.gov.cn/sydw/nhyzj/gzdt/200912/t20091207_211044 4.htm

Fisheries Administration Command Center of China (2010). The implementation of the Sino-Vietnamese Fishery agreement. China fisheries news (in Chinese), 7 June 2010.

Sohu News (2011). The 5th meeting of the Guiding Committee for bilateral cooperation between China and Vietnam was held in Hanoi (in Chinese). http://roll.sohu.com/20110906/n318561292.shtml

Zhang, Z. (2012). The fisheries evolution of the Beibu Gulf: Employment of Vietnamese due to labor shortage (in Chinese). http://china.huanqiu.com/border/2012-05/2747257.html

The agreement on fishery cooperation between China and Vietnam (in Chinese). (2012).

http://www.fmprc.gov.cn/chn/gxh/zlb/tyfg/t556668.htm

Ministry of Foreign Affairs of the People's Republic of China (2012). The Fisheries Bureau of China and the Marine Police of Vietnam carry out joint marine inspection together in the Beibu Gulf (in Chinese).

http://www.nhyzchina.gov.cn/sites/MainSite/Detail.aspx?StructID=3 273

The Fisheries Administration Bureau of South China Sea Region (2012). The Ministry of Agriculture of China released the circular on the 2011 summer fishing ban in the South China Sea (in Chinese). http://www.moa.gov.cn/sydw/nhyzj/xzwg/201105/t20110513_21110 34.htm

Ministry of Foreign Affairs of Vietnam (2005). Vietnam-China subcommittee for fisheries cooperation operation strengthened. http://www.mofa.gov.vn/en/nr040807104143/nr040807105001/ns05 0317085215/view
Ministry of Foreign Affairs of Vietnam (2007). Vietnam, China inspect joint fishing area. http://www.mofa.gov.vn/en/nr040807104143/nr040807105001/ns07 1001093343/view

Vietnam Plus (2009). Vietnam, Hainan speed up economic cooperation. http://en.vietnamplus.vn/Home/Vietnam-Hainan-speed-up-economic -cooperation/20097/678.vnplus

Ministry of Foreign Affairs of Vietnam (2012). Vietnam protests Chinese unilateral fishing ban in the East Sea. http://www.mofa.gov.vn/en/tt_baochi/pbnfn/ns120123233459/view

Vu, H.-D. (2012) A bilateral network of marine protected areas between Vietnam and China: An alternative to the Chinese unilateral fishing ban in the South China Sea?

http://nghiencuubiendong.vn/download/doc_download/505-vu-hai-da ng-a-bilateral-network-of-marine-protected-areas-between-vietnam-a nd-china-an-alternative-to-the-chinese-unilateral-fishing-ban-in-the-s outh-china-sea

Wang, K.-H. (2001). Bridge over troubled waters: Fisheries cooperation as a resolution to the South China Sea conflicts. The Pacific Review, 14, 531-551. doi:10.1080/09512740110087320

Wang, M. (2003). Waves are blowing in Northern Ports (in Chinese). China ship survey, October, 32-34.

Wang, M. (2003). Reflections over the "BeiBuWan Event” (in Chinese). China Ship Survey, November, 30-34.

$\mathrm{Wu}, \mathrm{Z}$. (2006) Innovate the mode of joint fisheries inspection of the Beibu Gulf (in Chinese). China Fisheries News, 10 July 2006.

Wu, Z.-D., Zou, J.-W., \& Fu, D. (2009). Problems and countermeasures of implementing summer fishing closure season in Guangxi Province (in Chinese). Chinese Fisheries Economics, 2, 16-21.

Xue, G. (2006). Improved fisheries co-operation: Sino-Vietnamese fisheries agreement for the Gulf of Tonkin. The International Journal of Marine and Coastal Law, 21, 217-234. doi:10.1163/157180806777973059

Xue, G. (2007). International fisheries law and policy and China's practice (in Chinese). Qingdao: China Ocean University Press.

Yu, H., \& Yu, Y. (2008). Fishing capacity management in China: Theoretic and practical perspectives. Marine Policy, 32, 351-359. doi:10.1016/j.marpol.2007.07.004

Yuan, L., \& Bi, C. (2010). Obvious effect on fishery resources rehabilitation in the South China Sea (in Chinese). Guangxi Daily, 26 April 2010.

Zou, K. (2002). Sino-Vietnamese fishery agreement for the Gulf of Tonkin. The International Journal of Marine and Coastal Law, 17, 127-146.

Zou, J., Lin, J., \& Mu, Y. (2007). Review and suggestion on decreasing of marine fishing vessels \& fishers' quitting fishing in Beihai, Guangxi (in Chinese). Chinese Fisheries Economics, 6, 61-64. 